\title{
Uncovering Patterns Among Latent Variables: Human Rights and De Facto Judicial Independence
}

\author{
Charles D. Crabtree Christopher J. Fariss*
}

August 12, 2015

\begin{abstract}
In this paper, we reexamine the relationship between judicial independence and state respect for human rights by taking advantage of new latent measures of both constructs. In our analysis, we demonstrate a simple method for incorporating the uncertainty of these latent variables. Results provide strong support for theoretical and empirical claims that independent courts are associated with human rights. Though we show that independent courts influence state behavior, the strength of the estimated relationship depends upon whether and to what degree empirical models account for uncertainty in the measurement of the latent variables.
\end{abstract}

Research \& Politics (Forthcoming)

\footnotetext{
${ }^{*}$ We would like to thank Luke Keele, Linda Camp Keith, Mark Major, Keith Schnakenberg, and Jeffrey Staton for many helpful comments and suggestions. This research was supported by The McCourtney Institute for Democracy Innovation Grant 2015, Pennsylvania State University. All data files necessary to replicate the analysis presented in the article are publicly available at dataverse repositories maintained by the authors: https://dataverse.harvard.edu/dataverse/CJFariss and https://dataverse.harvard. edu/dataverse/cdcrabtree
} 


\section{INTRODUCTION}

Do independent courts constrain states from abusing human rights? Prior studies have analyzed the extent to which formal provisions for judicial independence, such as constitutional protections against executive interference, are associated with respect for human rights. While the empirical evidence presented in these studies is mixed, recent research suggests a strong positive correlation between judicial independence and state respect for human rights (see Keith (2012) for a comprehensive review of this literature).

By focusing on de jure rather than de facto judicial independence, these studies might incorrectly estimate the true relationship between independent courts and respect for human rights. Most constitutions contain provisions that empower the judiciary to "check state power" (Keith, 2012, 2), but these provisions are not necessarily a strong predictor of the extent to which courts can act independently of the executive (Herron and Randazzo, 2003; Linzer and Staton, 2011). Even if the law guarantees courts specific powers, a regime could still constrain judicial authority by ignoring legal restrictions or by creating other laws, institutions, and norms that erode judicial independence (Silverstein, 2008). Alternatively, even if a state constitution does not empower the judiciary, courts might still find a way to exert influence and limit state terror (Ginsburg and Moustafa, 2008, 17).

To address this important distinction, Keith (2012) examines the effect of de facto judicial independence on political repression and finds compelling evidence that independent courts constrain human rights abuses. The measures that she uses to capture these constructs do not account, though, for the fact that both de facto judicial independence and state respect for human rights are not perfectly observable. That is, they are latent constructs that can only be estimated using observable indicators, which might sometimes be biased relative to the theoretical concepts of interest. Left unacknowledged, this measurement issue may obscure the true relationship between de facto judicial independence and state respect for human rights.

In this research note, we reexamine the relationship between de facto judicial independence and state respect for human rights, taking advantage of new latent variables for both of these important 
concepts (Fariss, 2014; Linzer and Staton, 2011). Latent variable models focus on the theoretical relationship between data and model parameters and offer scholars a principled way to bring together different pieces of information even if that information is in someway biased relative to the theoretical concept of interest (Fariss, 2015). Thus, the latent human rights and de facto judicial independence variables provide more valid measurements of these important theoretical concepts by bringing together multiple related indicators and linking them together using principled and transparent measurement models. In our analysis, we also demonstrate how to account for the uncertainty in the relative values of the country-year latent variable estimates. The results provide strong support for the theoretical and empirical claims in Keith (2012). The existence of independent courts is associated with greater respect for human rights.

\section{Model SPECIFICATION AND RESUltS}

To examine the relationship between de facto judicial independence and state respect for human rights, we use a common model specification in the human rights literature (Poe and Tate, 1994; Keith, 2002; Keith, Tate and Poe, 2009; Keith, 2012). The model regresses a measure of state respect for human rights on a lagged outcome measure and a series of variables that capture differences in "domestic and external threats (civil and/or international war), regime type (democracy, military, and leftist), and socioeconomic conditions (economic development, population size, and colonial legacy)" (Keith, 2012, 79). This model allows us to more easily build upon past empirical findings (Keith, 2012, 68). ${ }^{1}$ We make three important changes to the specification of this model.

The first change we make is to replace the usual outcome measures with a latent measure of state respect for human rights. Prior studies of the relationship between judicial independence and state respect for human rights typically use measures provided by or adapted from State Department and Amnesty International country year reports (Cross, 1999; Keith, Tate and Poe, 2009; Powell and Staton, 2009). However, the reporting standards of these organizations have changed, obscuring the true patterns of human rights practices over time (Fariss, 2014). The latent measure accounts for

\footnotetext{
${ }^{1}$ In Appendix A, we describe the variables used in our model.
} 
systematic changes to the human rights country reports published annually by the State Department and Amnesty International (Fariss, 2014).

The second change we make is to include a latent measure of de facto judicial independence developed by Linzer and Staton (2011). This variable improves on the measure developed by Keith (2012) in several important ways. The latent variable treats de facto judicial independence as an unobservable construct that can only be measured with uncertainty. This is important because, much like measures of human rights, observers cannot be certain of the precise level of de facto judicial independence for one country-year relative to another. ${ }^{2}$ Uncertainty is important substantive information necessary for comparing the relationship between complex theoretical concepts across political contexts and over time (Fariss, 2015; Schnakenberg and Fariss, 2014). The latent variable model provides a principled method for estimating the uncertainty of the country-year units. If we did not incorporate this information into the regression model, we would need to interpret our results under the strong assumption that we had perfectly operationalized and measured this theoretical concept.

In their measurement model, Linzer and Staton (2011) combine data from 12 different observable indicators (manifest variables) that are theoretically related to de facto judicial independence, which ensures that the latent variable estimates are not overly reliant on any single indicator. The incorporation of many observable indicators is a useful feature of latent variable models both in general and in this particular case. This is because Keith (2012) constructs her measure of de facto judicial independence from a single source, the Department of State human rights reports. These reports are potentially biased in favor of American "allies for security and political reasons" (Keith, 2012, 74) and U.S. trade partners Poe, Carey and Vazquez (2001, 677). These potential biases might obscure the empirical relationship between de facto judicial independence and human rights. As Jackman (2008) points out, a researcher with only one indicator of a latent construct is

\footnotetext{
${ }^{2}$ The Keith (2012) variable is an three-level ordinal measure, while the Linzer and Staton (2011) variable can take any value from $0-1$. The greater range of values for the latent measure allows us to estimate the effect of small over-time changes in de facto judicial independence. This is important if we think that judicial independence changes incrementally rather than categorically from year to year, as the variable used by Keith $(2012,159)$ implicitly suggests. See Appendix $\mathrm{G}$ for more discussion on estimator choices using continuous latent variable estimates.
} 
unable to determine how much variation in the indicator is due to measurement error as opposed to other forms of variation in the latent construct. By using the latent variable of de facto judicial independence in our regression model, we reduce the risk that any possible State Department bias is driving the results.

While the Linzer and Staton (2011) latent variable model incorporates the de facto judicial independence variable developed by Keith (2012), any bias from this particular variable is reduced with respect to the estimate of the latent variable if the other indicators in the measurement model do not share the same biases. Scholars still concerned that one or more manifest variables are biasing the Linzer and Staton (2011) measure can use the publicly available data and code to exclude one or more of these variables from the latent variable model. In light of concerns that the Linzer and Staton (2011) measurement model includes such a measure - the proportion of money that is held in banking institutions or the Contract Intensive Measure score (CIM) - we reestimate our regression model with a modified de facto judicial independence variable that excludes it. ${ }^{3}$

The third change we make to the regression model is to replace the measure of democracy with the Democracy-Dictatorship (DD) measure (Cheibub, Gandhi and Vreeland, 2010). Most earlier human rights studies use Polity or Freedom House measures of democracy. This is problematic because the Polity and Freedom House indicators classify regimes, in part, based on their respect for human rights (Hill Jr, 2014; Hill Jr and Jones, 2014). The concern is that using these measures causes us to partially control for the variable we are interested in examining and prevents us from assessing the independent effect of regime type on state respect for human rights. Following Poe and Tate (1994), who state that democracy "must be defined in terms that allow independent operationalization of the concept" (856), we use a measure of democracy that does not include state human rights practices. The DD measure is ideal for this as it measures democracy by whether free and contested elections have occured (Cheibub, Gandhi and Vreeland, 2010, 69). While the results

\footnotetext{
${ }^{3}$ In the results of the model with the modified de facto judicial independence variable, which we present in Appendix $\mathrm{C}$, the estimated slope of de facto judicial independence is larger, while the statistical significance of that coefficient is virtually unchanged. This is not surprising, since the point estimates for the original and modified measure are correlated at 0.988 for the country years in our dataset. We thank one of our reviewers for bringing this potential issue to our attention and Jeffrey Staton for sharing this alternative latent variable with us for these tests.
} 
we present include this measure, they are robust to using other alternative indicators of regime type (i.e. the Polity measure used in Keith (2012), the Freedom House and Polity measures used in Keith, Tate and Poe (2009), and the GWF Autocratic Regimes measure (Geddes, Wright and Frantz, 2014)). ${ }^{4}$

Since the latent human rights variable is continuous, we test the theoretical expectation that increases in de facto judicial independence are related to increases in state respect for human rights using ordinary least squares (OLS) regression with robust standard errors. ${ }^{5}$ Both of these choices are consistent with models presented in earlier work (Poe, Tate and Keith, 1999; Keith, Tate and Poe, 2009). For our primary models, we use data from Keith, Tate and Poe (2009) and Keith (2012) but include different indicators of (1) state respect for human rights (Fariss, 2014), (2) de facto judicial independence (Linzer and Staton, 2011), and (3) democracy (Cheibub, Gandhi and Vreeland, 2010). ${ }^{6}$

Figure 1 plots the point estimates from the OLS model along with $90 \%$ and $95 \%$ confidence intervals. In contrast with previous research (Cross, 1999; Keith, Tate and Poe, 2009; Keith, 2012; Powell and Staton, 2009), this model specification provides no evidence that increased judicial independence decreases state respect for human rights. While the point estimate for de facto judicial independence is positive, the standard error is larger than the point estimate.

The results presented in Figure 1, however, do not account for uncertainty in the point estimates of the outcome variable. As discussed above, researchers should take into account uncertainty when they cannot be sure about the precise value of the operationalized construct for one unit relative to another unit. ${ }^{7}$ So far, we have used the point estimates of the latent variable (mean of

\footnotetext{
${ }^{4}$ Appendix B presents a correlation matrix with de facto judicial independence and these democracy measures.

${ }^{5}$ We discuss the choice of the OLS estimator and alternatives in more detail in Appendix G.

${ }^{6}$ We thank Linda Camp Keith for providing us with the data used in Keith, Tate and Poe (2009); Keith (2012).

${ }^{7}$ With OLS, we gain insight into the uncertainty about the relationship between the dependent variable and all the independent variables in the model. This uncertainty in the relationship between dependent variables and independent variables does not reflect uncertainty in the measurement of the variables included in the model however. For a single regression model, one assumes that all the independent variables are measured without error. Any statistically significant relationship is based entirely on the relationship between dependent variable and independent variables because the point estimates are assumed to be precisely measured. We know this is not the case for the latent variables. It is therefore important to also incorporate the estimated measurement uncertainty from these variables into the regression
} 


\section{Figure 1: Effect of De Facto Judicial Independence on State Respect for Human Rights}

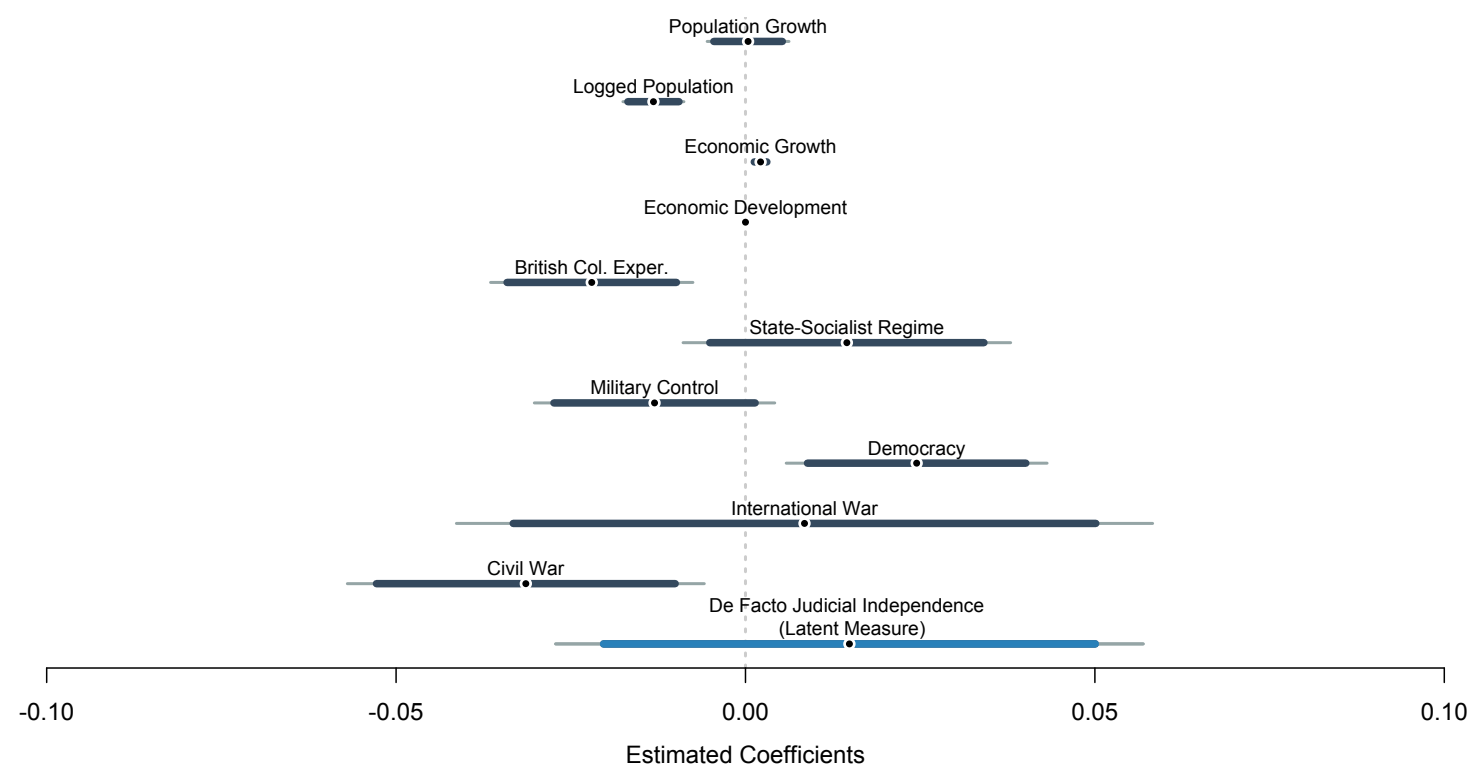

Note: Figure 1 presents the results of an OLS model, Model 1 in Table 1, that estimates the effect of several possible determinants on state respect for human rights. The bars on either side of the point estimates represent $90 \%$ and $95 \%$ confidence intervals. Confidence intervals are calculated with robust standard errors. While we include a lagged outcome measure in our model, we do not present an estimate for it here. See text for additional details. 
the posterior distribution) to estimate our model but we have ignored the standard deviation of the posterior distribution. To incorporate the information from these country-year distributions, we follow recommendations from Schnakenberg and Fariss (2014) by duplicating our dataset 1,000 times and assigning a random draw from the posterior distribution of the latent variable to each country-year observation. We use this new value as the outcome measure. We also perform the same procedure for the lagged outcome measure. We then estimate a set of 1,000 OLS models, combining the results across the the multiple sets of data to create one set of coefficient and standard error estimates. This procedure is substantively important because it allows us to to relax the assumption that theoretically important variables are measured perfectly and without error (Mislevy, 1991; Schnakenberg and Fariss, 2014). The equation used to combine the estimates from each of the 1,000 OLS models was developed by Rubin (1987) to combine estimates from multiply imputed datasets. Mislevy (1991) and Schnakenberg and Fariss (2014) discuss this approach in the context of latent variable models.

Figure 2 presents the results. The point estimate for de facto judicial independence is larger than in the base OLS model and the standard errors are now much smaller. These differences occur because we have relaxed both (a) the assumption that we have perfectly measured the latent variable on the right-hand side of the regression model and also (b) the relationship between the latent human rights variable and its value in the previous year. As a result, de facto judicial independence is now statistically significant and substantively quite large. A change in de facto judicial independence from the $25 \%$ to $75 \%$ percentile is associated with a 0.11 increase in state respect for human rights. In comparison, the occurrence of civil war, long considered the most important predictor of increased human rights abuse (Keith, 2012), is associated with a 0.15 decrease in state respect for human rights. This evidence suggests that independent courts play a meaningful role in checking human rights abuses.

estimates. This is especially true because the measurement error between the latent dependent variable and lagged latent dependent variable are conceptually and empirically related to one another. 
Figure 2: Effect of De Facto Judicial Independent on State Respect for Human Rights (Accounting for Uncertainty in the Outcome Measure and the Lagged Outcome Measure)

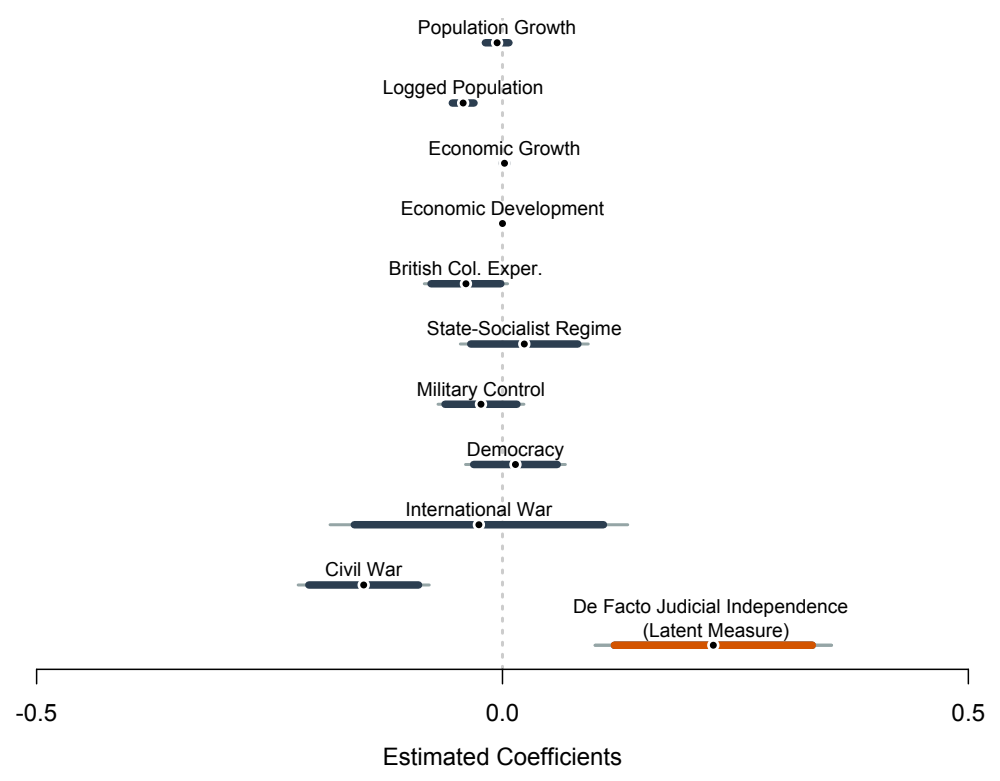

Note: Figure 2 presents the averaged results of 1,000 OLS models, each of which was estimated on a different set of draws from the posterior distribution of the outcome measure and the lagged outcome measure. The combined results of these models are presented in Model 2 in Table 1. The bars on either side of the point estimates represent $90 \%$ and 95\% confidence intervals. Confidence intervals are calculated with robust standard errors. While we include a lagged outcome measure in our model, we do not present an estimate for it here. See text for additional details. 
Since our key explanatory variable, de facto judicial independence, is also a latent construct, we need to account for uncertainty in its measurement as well. We do so using the process described above. In Figure 4, we present the results of re-estimating our model with new values for the judicial independence measure. Table 1 presents this model and the earlier models, allowing for easy comparison. As in the previous model, we find that an increase in de facto judicial independence variable is associated with a substantially large increase in respect for human rights. While the magnitude of this increase is marginally smaller than in the previous model, the effect of this change is still greater than the individual effect of other variables in the model, with the exceptions of the lagged dependent variable and the civil war measure. This provides additional evidence for a strong positive correlation between judicial independence and state respect for human rights. ${ }^{8}$

To demonstrate the importance of incorporating uncertainty in the measurement of latent constructs, we compare the estimates of de facto judicial independence. Figure 4 plots the point estimates for de facto judicial independence from each model with $90 \%$ and $95 \%$ confidence intervals. The figure illustrates that if we do not account for uncertainty in the measurement of the outcome and lagged outcome measures, we might underestimate the possible effect of de facto judicial independence on state respect for human rights. Indeed, we would infer that there was not a statistically significant association. The figure also shows that if we do not take into account uncertainty in the measurement of de facto judicial independence, we would slightly overestimate its effect. Only by accounting for uncertainty in both latent variables can we estimate the relationship between them based on both the uncertainty of the relationship between outcome measure and independent variables (the uncertainty that OLS regression captures) and the uncertainty in the measurement of the independent variables themselves (the uncertainty that a latent variable model captures).

\footnotetext{
${ }^{8}$ These results are robust to using the model and data from Keith, Tate and Poe (2009) (see Appendix E). That we obtain similar results using a different model and data suggests that our findings are not driven by our model specification or the cases in our dataset. They are also robust to lagging the latent measure of de facto judicial independence and to several alternative model specifications presented in Appendices D and F.
} 
Figure 3: Effect of De Facto Judicial Independent on State Respect for Human Rights (Accounting for Uncertainty in the Outcome Measure, the Lagged Outcome Measure, and the Indepndent Variable)

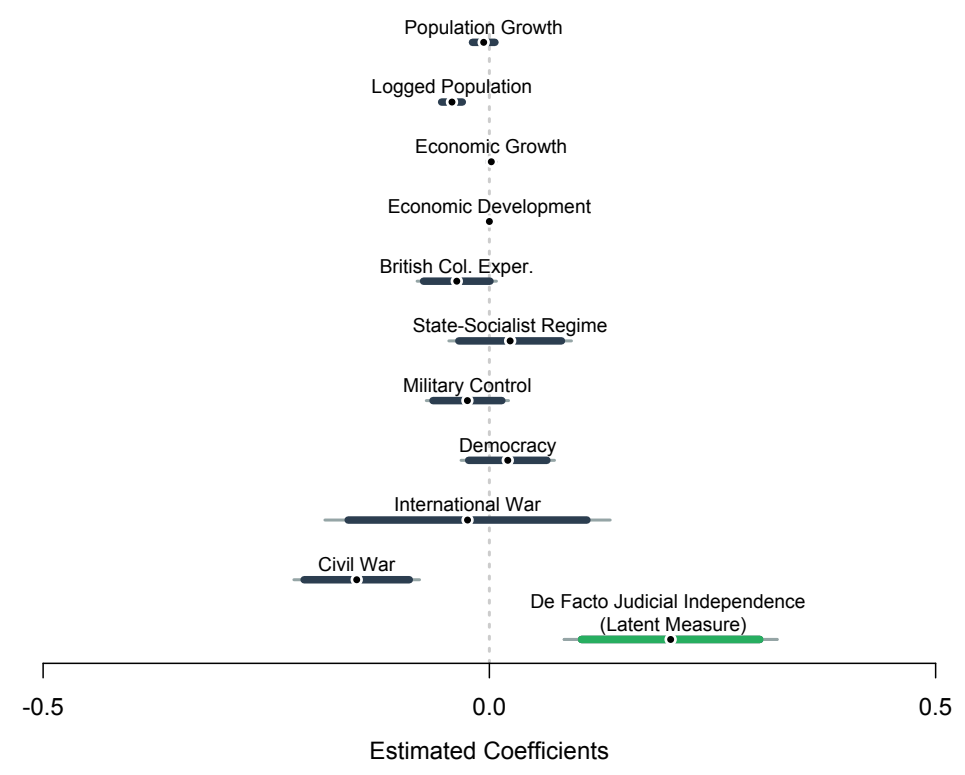

Note: Figure 3 presents the averaged results of 1,000 OLS models, each of which was estimated on a different set of draws from the posterior distribution of the outcome measure, the lagged outcome measure, and the primary independent variable. The combined results of these models are presented in Model 3 in Table 1. The bars on either side of the point estimates represent $90 \%$ and $95 \%$ confidence intervals. Confidence intervals are calculated with robust standard errors. While we include a lagged outcome measure in our model, we do not present an estimate for it here. See text for additional details. 
Figure 4: Comparing the Effect of De Facto Judicial Independence Across Models

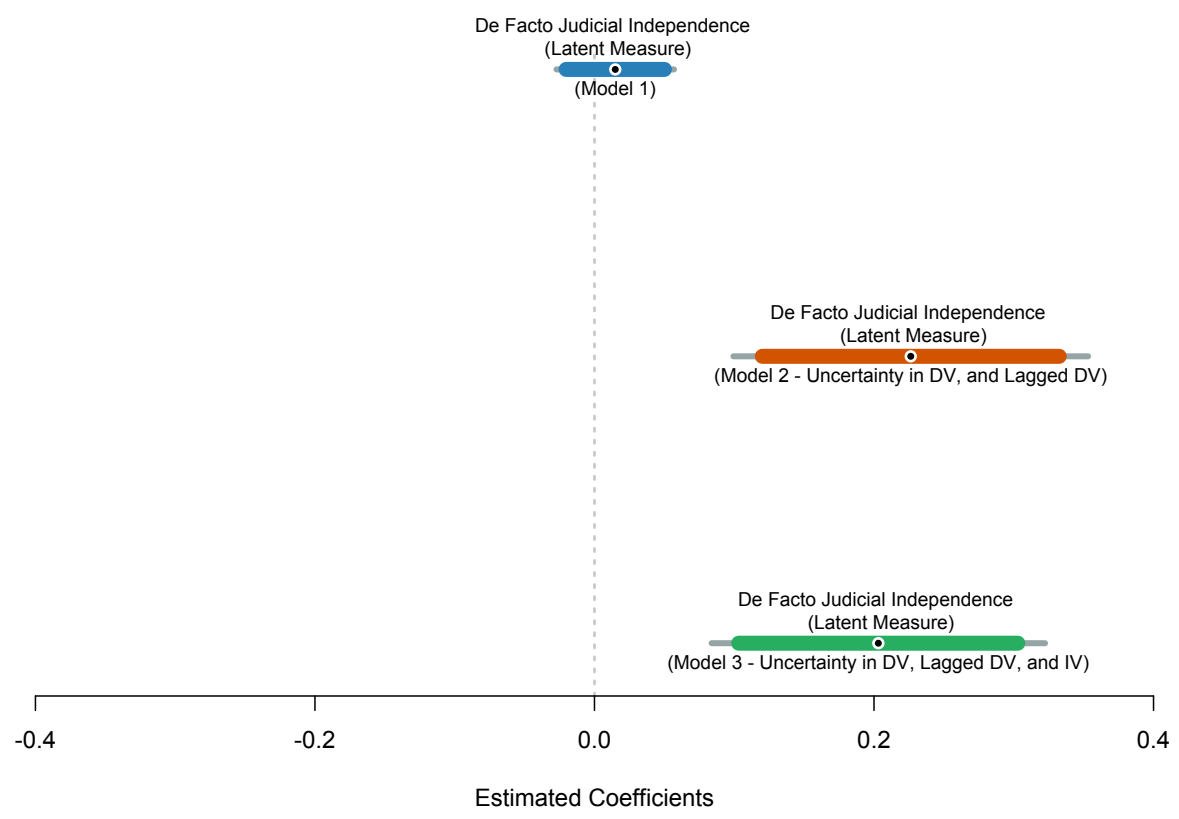

Note: Figure 4 plots the point estimates for de facto judicial independence from the three previous models. The bars on either side of the point estimates represent $90 \%$ and $95 \%$ confidence intervals. Confidence intervals are calculated with robust standard errors. The top model (blue line from Figure 1) regresses the point estimates for the latent human rights variable on the point estimates for the latent judicial independence measure in addition to the controls. The middle model (orange line from Figure 2) regresses 1,000 draws from the latent human rights variable on the point estimates for the latent judicial independence measure in addition to the controls. The lower model (green line from Figure 3) regresses 1,000 draws from the latent human rights variable on 1,000 draws from the latent judicial independence measure in addition to the controls. See text for additional details. 
Finally, we consider whether the findings are limited to the cases we include in the analysis. To guard against overfitting and "Type III error," we use $k$-fold cross validation (Efron and Gong, 1983; Hill Jr and Jones, 2014; Ward, Greenhill and Bakke, 2010). We run 1,000 simulations, randomly partitioning our data into one training set and nine test sets $(k=10)$ and estimate a series of models. Table 2 presents the OLS results from these models. The baseline model (Model 1) includes only the lagged outcome measure; other models contain combinations of explanatory variables. Figure 5 plots the cross validation results, specifically the average percent reduction in mean square error of each model compared to the baseline model. This reveals the additional predictive power of individual variables and combinations of variables. As shown in the figure, we reduce more error by including the latent judicial independence measure in the model than we do by including other theoretically important variables. De facto judicial independence is a substantively important predictor of increased state respect for human rights.

\section{CONCLUSION}

We have reexamined the finding from Keith (2012) that de facto judicial independence is positively associated with state respect for human rights, taking advantage of new latent measures of both constructs. We have also demonstrated how to incorporate the uncertainty in the latent variables used in our analysis. Though the relationship depends upon whether and to what degree our empirical models account for uncertainty in the measurement of latent constructs, increased de facto judicial independence appears to be associated with a substantial decrease in human rights abuses. Overall, the results provide strong support for theoretical and empirical claims that the existence of independent courts is associated with greater respect for human rights (Cross, 1999; Keith, 2012; Keith, Tate and Poe, 2009; Powell and Staton, 2009; Lupu, 2013). 
Figure 5: Cross-Validation Results
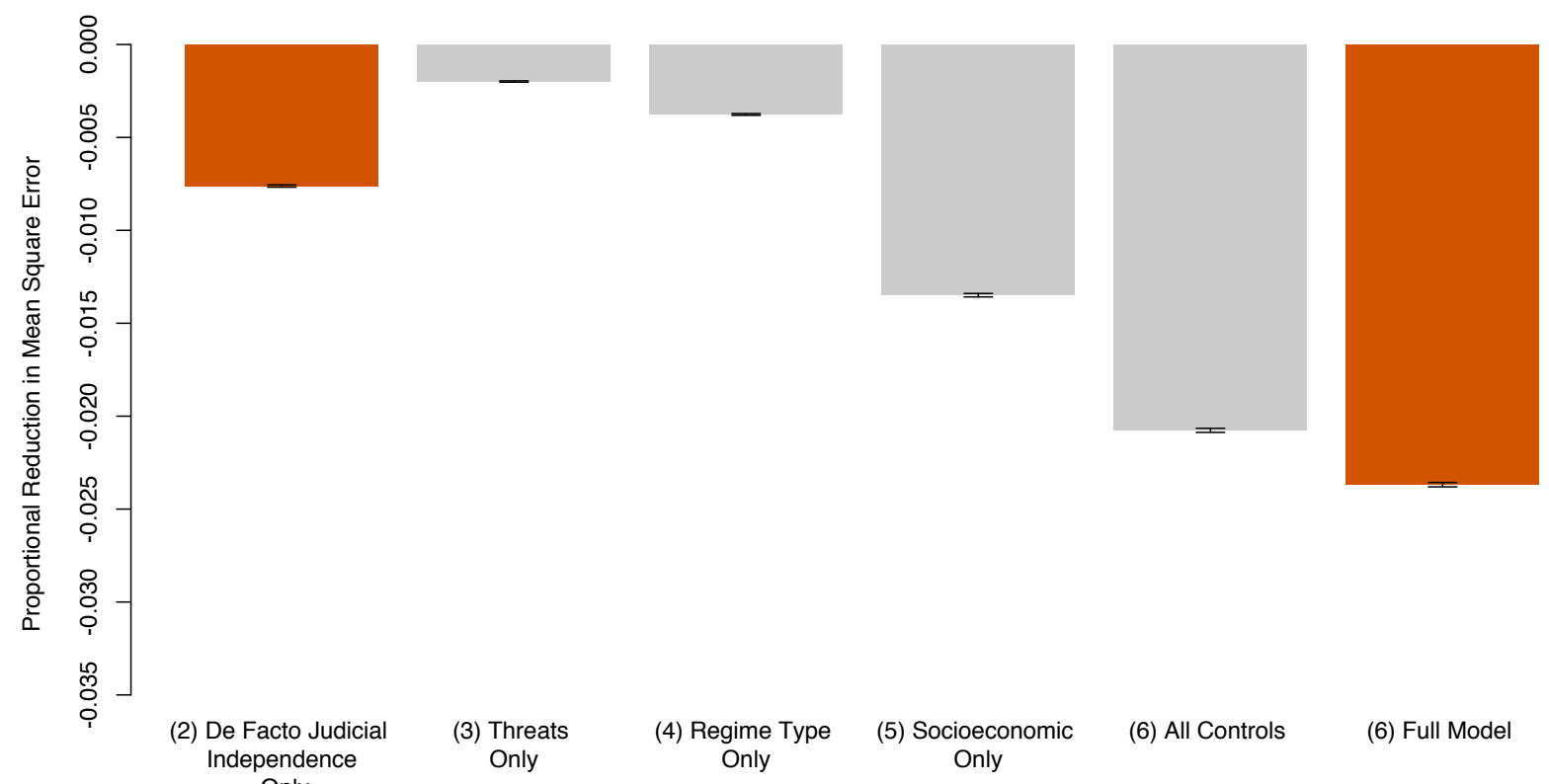

Only

Threats
Only

(4) Regime Type

(5) Socioeconomic Only

(6) All Controls

(6) Full Model

Models

Note: Figure 5 plots the average percent reduction in mean square error of each model compared to the baseline model, which includes only the lagged outcome measure, revealing the additional predictive power of individual variables and combinations of variables. Each bar in the figure corresponds to a model reported in Table 2. Model 1 is the baseline model that all other models are compared to. Thus, Bar 2 corresponds to Model 2, Bar 3 corresponds to Model 3, Bar 4 corresponds to Model 4, Bar 5 corresponds to Model 5, and Bar 6 corresponds to Model 6. The black lines bracketing the end of each column represent $95 \%$ confidence intervals. See text for additional details. 
Table 1: State Respect for Human Rights Across Countries (1980-2004)

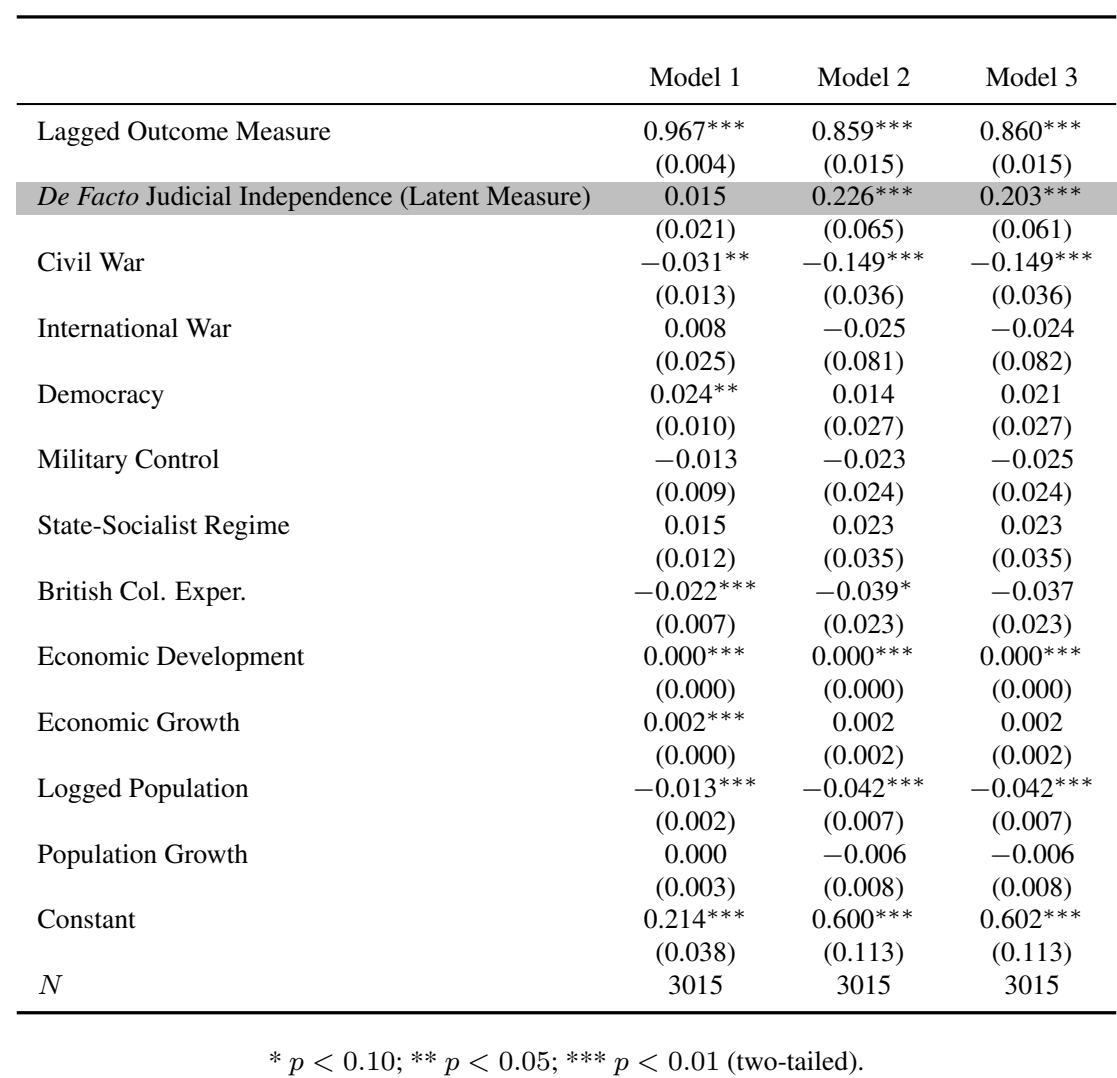

Note: Robust standard errors are shown in parentheses. Data come from 3015 country-year observations from 1980 to 2004. The outcome measure is State Respect for Human Rights. See Keith (2012) for more information about the model and data. 
Table 2: State Respect for Human Rights Across Countries (1980-2004) - Models Used for Cross Validation

\begin{tabular}{lcccccc}
\hline & & & & & \\
& Model 1 & Model 2 & Model 3 & Model 4 & Model 5 & Model 6 \\
\hline Lagged Outcome Measure & $0.918^{* * *}$ & $0.940^{* * *}$ & $0.935^{* * *}$ & $0.900^{* * *}$ & $0.874^{* * *}$ & $0.860^{* * *}$ \\
& $(0.011)$ & $(0.011)$ & $(0.011)$ & $(0.013)$ & $(0.014)$ & $(0.015)$ \\
De Facto Judicial Independence (Latent Measure) & $0.211^{* * *}$ & - & - & - & - & $0.203^{* * *}$ \\
Civil War & $(0.040)$ & - & - & - & - & $(0.061)$ \\
& - & $-0.112^{* * *}$ & - & - & $-0.146^{* * *}$ & $-0.149^{* * *}$ \\
International War & - & $(0.037)$ & - & - & $(0.037)$ & $(0.036)$ \\
& - & -0.016 & - & - & -0.016 & -0.024 \\
Democracy & - & $(0.083)$ & - & - & $(0.082)$ & $(0.081)$ \\
& - & - & $0.059^{* * *}$ & - & $0.079^{* * *}$ & 0.021 \\
Military Control & - & - & $(0.021)$ & - & $(0.022)$ & $(0.027)$ \\
State-Socialist Regime & - & - & -0.048 & - & $-0.039^{*}$ & -0.025 \\
British Col. Exper. & - & - & $(0.024)$ & - & $(0.023)$ & $(0.024)$ \\
& - & - & -0.009 & - & 0.023 & 0.023 \\
Economic Development & - & - & $(0.035)$ & - & $(0.035)$ & $(0.035)$ \\
Economic Growth & - & - & -0.005 & - & -0.014 & -0.037 \\
& - & - & $(0.022)$ & - & $(0.022)$ & $(0.023)$ \\
Logged Population & - & - & - & $0.000^{* * *}$ & $0.000^{* * *}$ & $0.000^{* * *}$ \\
Population Growth & - & - & - & $(0.000)$ & $(0.000)$ & $(0.000)$ \\
Constant & - & - & - & 0.002 & 0.002 & 0.002 \\
$N$ & - & - & - & $(0.002)$ & $(0.002)$ & $(0.002)$ \\
& - & - & - & $-0.032^{* * *}$ & $-0.039^{* * *}$ & $-0.042^{* * *}$ \\
& $-0.020)$ & $(0.010)$ & $(0.018)$ & $(0.112)$ & $(0.113)$ & $(0.113)$ \\
& -3015 & 3015 & 3015 & 3015 & 3015 & 3015 \\
\hline
\end{tabular}

$* p<0.10 ; * * p<0.05 ; * * * p<0.01$ (two-tailed).

Note: Robust standard errors are shown in parentheses. All models account for uncertainty in the outcome measure, the lagged outcome measure, and the indepndent variable. Data come from 3015 country-year observations from 1980 to 2004. The outcome measure is State Respect for Human Rights. See Keith (2012) for more information about the model and data. 


\section{REFERENCES}

Cheibub, José Antonio, Jennifer Gandhi and James Raymond Vreeland. 2010. "Democracy and dictatorship revisited." Public Choice 143(1-2):67-101.

Cross, Frank B. 1999. "The relevance of law in human rights protection." International Review of Law and Economics 19(1):87-98.

Efron, Bradley and Gail Gong. 1983. "A leisurely look at the bootstrap, the jackknife, and crossvalidation." The American Statistician 37(1):36-48.

Fariss, Christopher J. 2014. "Respect for Human Rights Has Improved Over Time: Modeling the Changing Standard of Accountability.” American Political Science Review 108(2):297-318.

Fariss, Christopher J. 2015. "Human Rights Treaty Compliance and the Changing Standard of Accountability." British Journal of Political Science .

Geddes, Barbara, Joseph Wright and Erica Frantz. 2014. "Autocratic breakdown and regime transitions: A new data set." Perspectives on Politics 12(02):313-331.

Ginsburg, Tom and Tamir Moustafa. 2008. Rule by law: the politics of courts in authoritarian regimes. Cambridge University Press Cambridge.

Herron, Erik S and Kirk A Randazzo. 2003. "The relationship between independence and judicial review in post-communist courts." Journal of Politics 65(2):422-438.

Hill Jr, Daniel W. 2014. "Democracy and The Concept of Personal Integrity Rights In Empirical Research.”.

Hill Jr, Daniel W and Zachary M Jones. 2014. An Empirical Evaluation of Explanations for State Repression. In American Political Science Review. Vol. 108 pp. 661-687.

Jackman, Simon. 2008. Measurement. In The Oxford Handbook of Political Methodology, ed. Janet M. Box-Steffensmeier, Henry E. Brady and David Collier. Oxford University Press. 
Keith, Linda Camp. 2002. “Constitutional provisions for individual human rights (1977-1996): Are they more than mere "window dressing?"." Political Research Quarterly 55(1):111-143.

Keith, Linda Camp. 2012. Political Repression Courts and the Law. University of Pennsylvania Press.

Keith, Linda Camp, C Neal Tate and Steven C Poe. 2009. "Is the Law a Mere Parchment Barrier to Human Rights Abuse?” The Journal of Politics 71(02):644-660.

Linzer, Drew A and Jeffrey K Staton. 2011. A measurement model for synthesizing multiple comparative indicators: The case of judicial independence. In presentation at the 2011 Annual Meeting of the American Political Science Association, September. pp. 1-4.

Lupu, Yonatan. 2013. "Best Evidence: The Role of Information in Domestic Judicial Enforcement of International Human Rights Agreements.” International Organization 67(3):469-503.

Mislevy, Robert. 1991. "Randomization-based inference about latent variables from complex samples." Psychometrika 56(2):177-196.

Poe, Steven C. and C. Neal Tate. 1994. "Repression of Human Rights to Personal Integrity in the 1980s: A Global Analysis.” American Political Science Review 88(4):853-872.

Poe, Steven C., C. Neal Tate and Linda Camp Keith. 1999. "Repression of the Human Right to Personal Integrity Revisited: A Global Cross-National Study Covering the Years 1976-1993." International Studies Quarterly 43(2):291-313.

Poe, Steven C., Sabine C. Carey and Tanya C. Vazquez. 2001. "How are These Pictures Different? A Quantitative Comparison of the US State Department and Amnesty International Human Rights Reports, 1976-1995." Human Rights Quarterly 23(3):650-677.

Powell, Emilia Justyna and Jeffrey K Staton. 2009. "Domestic judicial institutions and human rights treaty violation.” International Studies Quarterly 53(1):149-174. 
Rubin, Donald B. 1987. Multiple Imputation for Nonresponse in Surveys. New York, NY: J. Wiley \& Sons.

Schnakenberg, Keith E and Christopher J Fariss. 2014. "Dynamic Patterns of Human Rights Practices." Political Science Research and Methods 2(01):1-31.

Silverstein, Gordon. 2008. "Singapore: the exception that proves rules matter." Rule by law: the politics of courts in authoritarian regimes pp. 73-101.

Ward, Michael D., Brian D. Greenhill and Kristin M. Bakke. 2010. "The perils of policy by pvalue: Predicting civil conflicts.” Journal of Peace Research 47(4):1-13. 


\title{
Appendix: \\ Uncovering Patterns Among Latent Variables: Human Rights and De Facto Judicial Independence
}

\author{
Charles D. Crabtree Christopher J. Fariss*
}

August 12, 2015

CONTENTS

$\begin{array}{ll}\text { A Variable descriptions } & 3\end{array}$

B Correlation matrix with de facto judicial independence and democracy measures 5

$\begin{array}{lll}\text { C } & \text { Results from model that includes modified de facto judicial independence measure } & 7\end{array}$

D Results from model that only incorporates uncertainty in the primary independent variable

E Extension of Keith, Tate and Poe (2009) 13

F Models with Unified Democracy Score measure 21

$\begin{array}{lr}\text { G Notes on estimator choice } & 26\end{array}$

${ }^{*}$ This research was supported by The McCourtney Institute for Democracy Innovation Grant 2015, Pennsylvania State University. All data files necessary to replicate the analysis presented in the paper will be made publicly available at dataverse repositories maintained by the authors: https: / / dataverse.harvard.edu/dataverse/ CJFariss and https://dataverse.harvard.edu/dataverse/cdcrabtree 


\section{INTRODUCTION TO THE APPENDIX}

The supplementary material presented in this document provides additional details about robustness checks and empirical analysis decisions discussed in the article "Uncovering Patterns Among Latent Variables: Human Rights and De Facto Judicial Independence." The main article makes reference to the materials contained here. The code and data files necessary to conduct the analysis presented here are made publicly available at dataverse repositories maintained by the authors:

https: //dataverse.harvard.edu/dataverse/CJFariss and https: / / dataverse. harvard.edu/dataverse/cdcrabtree. 
A. VARIABLE DESCRIPTIONS 
Below we describe the variables included in our model. (Keith, 2012, 54-112) and Keith, Tate and Poe (2009) contain a fuller discussion of this model.

State Respect for Human Rights: An interval variable that captures the degree to which a state respects human rights in a given year $(t)$. Data from Fariss (2014).

Lagged Outcome Measure: An interval variable that captures the degree to which a state respects human rights in a previous year $(t-1)$. Data from Fariss (2014).

De Facto Judicial Independence: An interval variable bound between 0 and 1 that captures the degree to which courts can act independently in a state in a given year. Data from Linzer and Staton (2011). See (Keith, 2012, 152-154) for a discussion of her measure and Linzer and Staton (2011) for a discussion of the measure we use.

Civil War: A binary variable coded 1 if a state experienced a civil war in a given year, 0 otherwise. Data from Keith (2012). See Keith (2012, 79-80) for detailed discussion.

International War: A binary variable coded 1 if a state was in an international war in a given year, 0 otherwise. Data from Hallberg (2012). See Keith (2012, 80-82) for detailed discussion.

Democracy: A binary variable coded 1 if a state was a democracy in a given year, 0 otherwise. Data from Cheibub, Gandhi and Vreeland (2010). See Keith (2012, 82-84) for a general discussion of the effect of democracy on state respect respect for human rights and Cheibub, Gandhi and Vreeland (2010) for a discussion of the measure.

Military Control: A binary variable coded 1 is a state was controlled directly or indirectly by the military in a given year, 0 otherwise. Data from Keith (2012). See (Keith, 2012, 87) for detailed discussion.

State-Socialist Regime: A binary variable coded 1 if a state was run by a socialist party or coalition that does not permit non-socialist electoral opposition in a given year, 0 otherwise. Data from Keith (2012). See (Keith, 2012, 87-88) for detailed discussion.

British Col. Exper: A binary variable coded 1 if a state was a territory of Great Britain at some point in its history, 0 otherwise. Data from Keith (2012). See (Keith, 2012, 90-91) for detailed discussion.

Economic Development: The per-capita GDP of a state. Data from Keith (2012). See (Keith, 2012, 88-90) for detailed discussion.

Economic Growth: The percentage growth in GDP per-capita of a state. Data from Keith (2012). See (Keith, 2012, 88-90) for detailed discussion.

Logged Population: The logged national population of a state. Data from Keith (2012). See (Keith, 2012, 88-90) for detailed discussion.

Population Growth: The average percentage growth in national population of a state. Data from Keith (2012). See (Keith, 2012, 88-90) for detailed discussion. 
B. CORRELATION MATRIX WITH de facto JUDICIAL INDEPENDENCE AND DEMOCRACY MEASURES 


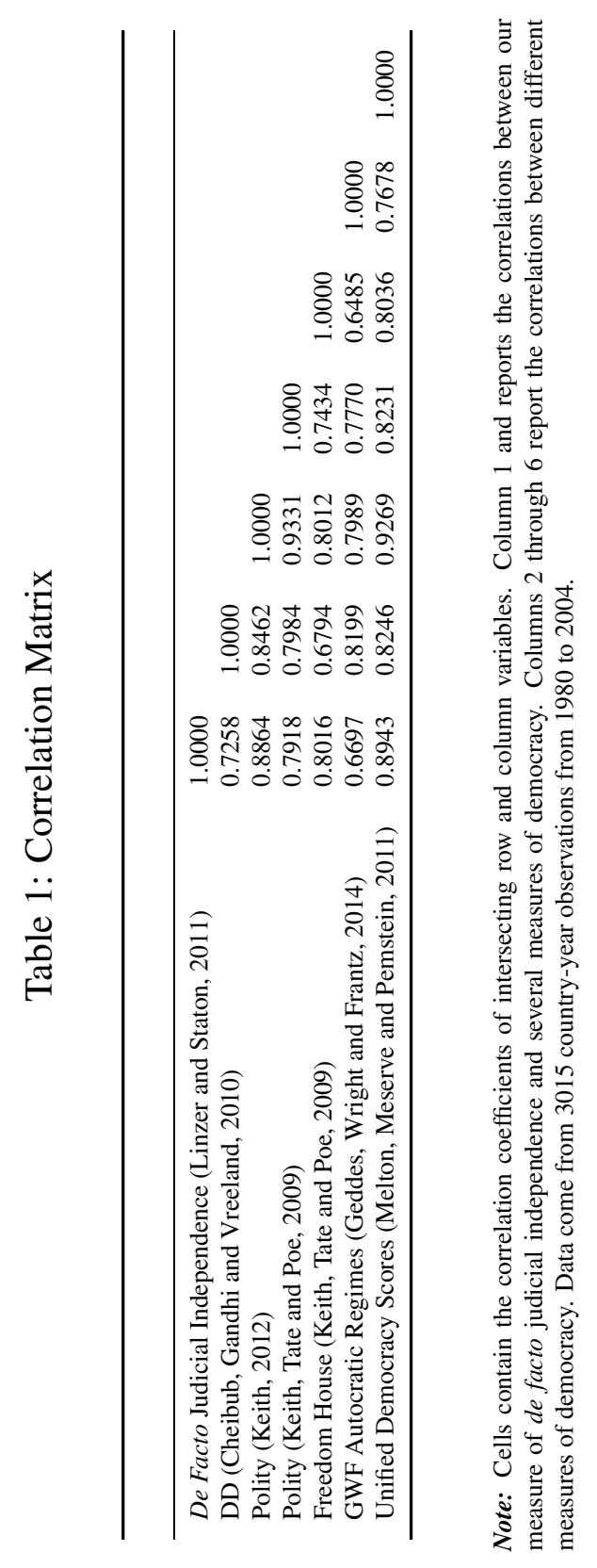


C. RESULTS FROM MODEL THAT INCLUDES MODIFIED de facto JUDICIAL INDEPENDENCE MEASURE 
We reestimate Model 3 from Table 1 with a modified version of the Linzer and Staton (2011) measure that excludes the Contract Intensive Measure score. Table presents the results. These results are also presented graphically in Figure 6.

Table 2: State Respect for Human Rights Across Countries (1980-2004)

\begin{tabular}{lc}
\hline & Model 1 \\
\hline Lagged Outcome Measure & $0.858^{* * *}$ \\
& $(0.015)$ \\
De Facto Judicial Independence (Latent Measure) & $0.213^{* * *}$ \\
Civil War & $(0.059)$ \\
& $-0.153^{* * *}$ \\
International War & $(0.036)$ \\
& -0.026 \\
Democracy & $(0.081)$ \\
& 0.009 \\
Military Control & $(0.028)$ \\
& -0.025 \\
State-Socialist Regime & $(0.024)$ \\
British Col. Exper. & 0.022 \\
& $(0.034)$ \\
Economic Development & -0.035 \\
& $(0.023)$ \\
Economic Growth & $0.000^{* * *}$ \\
& $(0.000)$ \\
Logged Population & $0.002^{* * *}$ \\
& $(0.000)$ \\
Population Growth & $-0.042^{* * *}$ \\
Constant & $(0.007)$ \\
$N$ & -0.006 \\
& $(0.007)$ \\
& $0.603^{* * *}$ \\
& $(0.112)$ \\
& 3015 \\
\hline
\end{tabular}

$$
* p<0.10 ; * * p<0.05 ; * * * p<0.01 \text { (two-tailed). }
$$

Note: Robust standard errors are shown in parentheses. The de facto judicial independence variable is a modified version of the (Linzer and Staton, 2011) measure that excludes the Contract Intensive Measure score. Data come from 3015 country-year observations from 1980 to 2004. The outcome measure is State Respect for Human Rights. See Keith (2012) for more information about the model and data. 
Figure 1: Effect of Modified De Facto Judicial Independence Measure on State Respect for Human Rights (Accounting for Uncertainty in the Outcome Measure and the Lagged Outcome Measure and the Independent Variable)

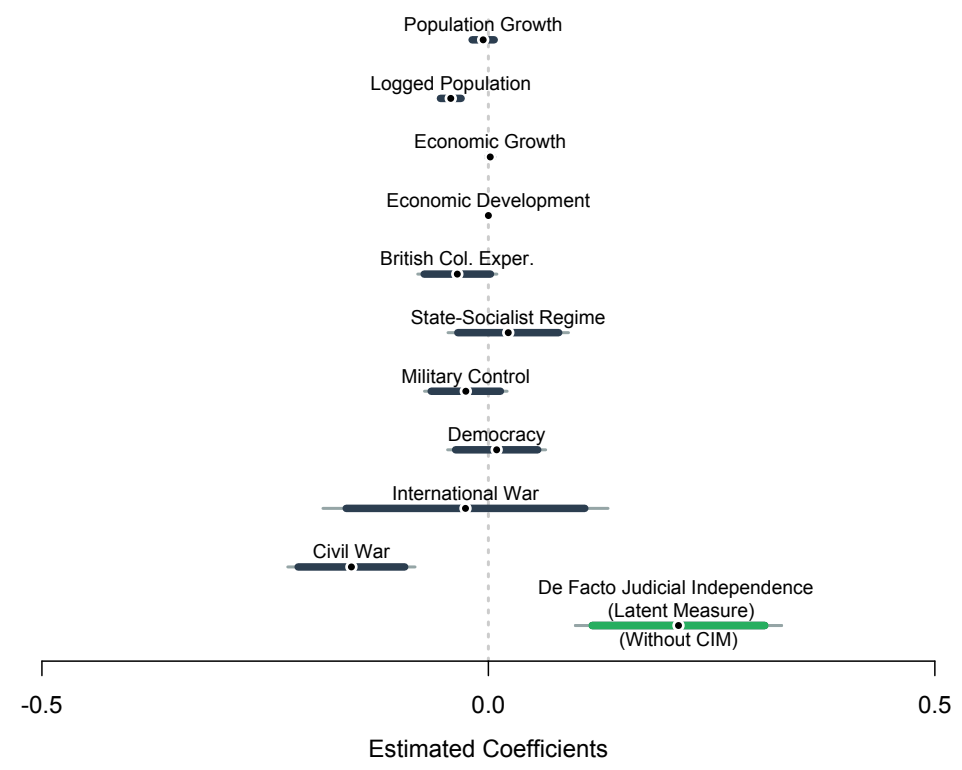

Note: Figure 6 presents the averaged results of 1,000 OLS models, each of which was estimated on a different set of draws from the posterior distribution of the outcome measure, the lagged outcome measure, and the primary independent variable. The primary independent variable is a modified version of the (Linzer and Staton, 2011) measure that excludes the Contract Intensive Measure score. The combined results of these models are presented in Model 1 in Table 1. The bars on either side of the point estimates represent $90 \%$ and $95 \%$ confidence intervals. Confidence intervals are calculated with robust standard errors. While we include a lagged outcome measure in our model, we do not present an estimate for it here. See text for additional details. 
D. RESULTS FROM MODEL THAT ONLY INCORPORATES UNCERTAINTY IN THE PRIMARY

INDEPENDENT VARIABLE 
We present an additional set of results here, where we only take into account of the uncertainty in the latent de facto judicial independence measure. This new set of results is presented in column 2 of Table 5. For ease of comparison, we have included here the other models presented in Table 1. Column 1 of Table 5 presents the results using the point estimates from the latent variable. Column 3 of Table 5 presents the results once we take into account the uncertainty in the outcome and lagged outcome measures. Finally, column 4 of Table 5 presents the results once we take into account the uncertainty in the outcome measure, the lagged outcome measure, and the independent variable. Figure 6 plots the point estimates for de facto judicial independence from these four models.

Table 3: State Respect for Human Rights Across Countries (1980-2004)

\begin{tabular}{|c|c|c|c|c|}
\hline & Model 1 & Model 2 & Model 3 & Model 4 \\
\hline Lagged Outcome Measure & $\begin{array}{c}0.967^{* * *} \\
(0.004)\end{array}$ & $\begin{array}{c}0.970^{* * *} \\
(0.015)\end{array}$ & $\begin{array}{c}0.859^{* * *} \\
(0.015)\end{array}$ & $\begin{array}{c}0.860^{* * *} \\
(0.015)\end{array}$ \\
\hline De Facto Judicial Independence (Latent Measure) & 0.015 & $(0.004)$ & $0.226^{* * *}$ & $0.203^{* * *}$ \\
\hline & $(0.021)$ & $(0.021)$ & $(0.065)$ & $(0.061)$ \\
\hline Civil War & $\begin{array}{c}-0.031^{* *} \\
(0.013)\end{array}$ & $\begin{array}{c}-0.031^{* *} \\
(0.013)\end{array}$ & $\begin{array}{c}-0.149^{* * *} \\
(0.036)\end{array}$ & $\begin{array}{c}-0.149^{* * *} \\
(0.036)\end{array}$ \\
\hline International War & $\begin{array}{c}0.008 \\
(0.025)\end{array}$ & $\begin{array}{c}0.008 \\
(0.025)\end{array}$ & $\begin{array}{l}-0.025 \\
(0.081)\end{array}$ & $\begin{array}{l}-0.024 \\
(0.082)\end{array}$ \\
\hline Democracy & $\begin{array}{c}0.024^{* *} \\
(0.010)\end{array}$ & $\begin{array}{l}0.025^{* *} \\
(0.009)\end{array}$ & $\begin{array}{c}0.014 \\
(0.027)\end{array}$ & $\begin{array}{c}0.021 \\
(0.027)\end{array}$ \\
\hline Military Control & $\begin{array}{l}-0.013 \\
(0.009)\end{array}$ & $\begin{array}{l}-0.013 \\
(0.009)\end{array}$ & $\begin{array}{l}-0.023 \\
(0.024)\end{array}$ & $\begin{array}{l}-0.025 \\
(0.024)\end{array}$ \\
\hline State-Socialist Regime & $\begin{array}{c}0.015 \\
(0.012)\end{array}$ & $\begin{array}{c}0.014 \\
(0.012)\end{array}$ & $\begin{array}{c}0.023 \\
(0.035)\end{array}$ & $\begin{array}{c}0.023 \\
(0.035)\end{array}$ \\
\hline British Col. Exper. & $\begin{array}{c}-0.022^{* * *} \\
(0.007)\end{array}$ & $\begin{array}{c}-0.022^{* * *} \\
(0.007)\end{array}$ & $\begin{array}{c}-0.039^{*} \\
(0.023)\end{array}$ & $\begin{array}{l}-0.037 \\
(0.023)\end{array}$ \\
\hline Economic Development & $\begin{array}{c}0.000^{* * *} \\
(0.000)\end{array}$ & $\begin{array}{c}0.000^{* * *} \\
(0.000)\end{array}$ & $\begin{array}{c}0.000^{* * *} \\
(0.000)\end{array}$ & $\begin{array}{c}0.000^{* * *} \\
(0.000)\end{array}$ \\
\hline Economic Growth & $\begin{array}{c}0.002^{* * *} \\
(0.000)\end{array}$ & $\begin{array}{c}0.002^{* * *} \\
(0.000)\end{array}$ & $\begin{array}{c}0.002 \\
(0.002)\end{array}$ & $\begin{array}{c}0.002 \\
(0.002)\end{array}$ \\
\hline Logged Population & $\begin{array}{c}-0.013^{* * *} \\
(0.002)\end{array}$ & $\begin{array}{c}-0.013^{* * *} \\
(0.002)\end{array}$ & $\begin{array}{c}-0.042^{* * *} \\
(0.007)\end{array}$ & $\begin{array}{c}-0.042^{* * *} \\
(0.007)\end{array}$ \\
\hline Population Growth & $\begin{array}{c}0.000 \\
(0.003)\end{array}$ & $\begin{array}{c}0.000 \\
(0.003)\end{array}$ & $\begin{array}{l}-0.006 \\
(0.008)\end{array}$ & $\begin{array}{l}-0.006 \\
(0.008)\end{array}$ \\
\hline Constant & $\begin{array}{c}0.214^{* * *} \\
(0.038)\end{array}$ & $\begin{array}{c}0.214^{* * *} \\
(0.037)\end{array}$ & $\begin{array}{c}0.600^{* * *} \\
(0.113)\end{array}$ & $\begin{array}{c}0.602^{* * *} \\
(0.113)\end{array}$ \\
\hline$N$ & 3015 & 3015 & 3015 & 3015 \\
\hline
\end{tabular}

Note: Robust standard errors are shown in parentheses. Data come from 3015 country-year observations from 1980 to 2004. The outcome measure is State Respect for Human Rights. See Keith (2012) for more information about the model and data. 
Figure 2: Comparing the Effect of De Facto Judicial Independence Across Models

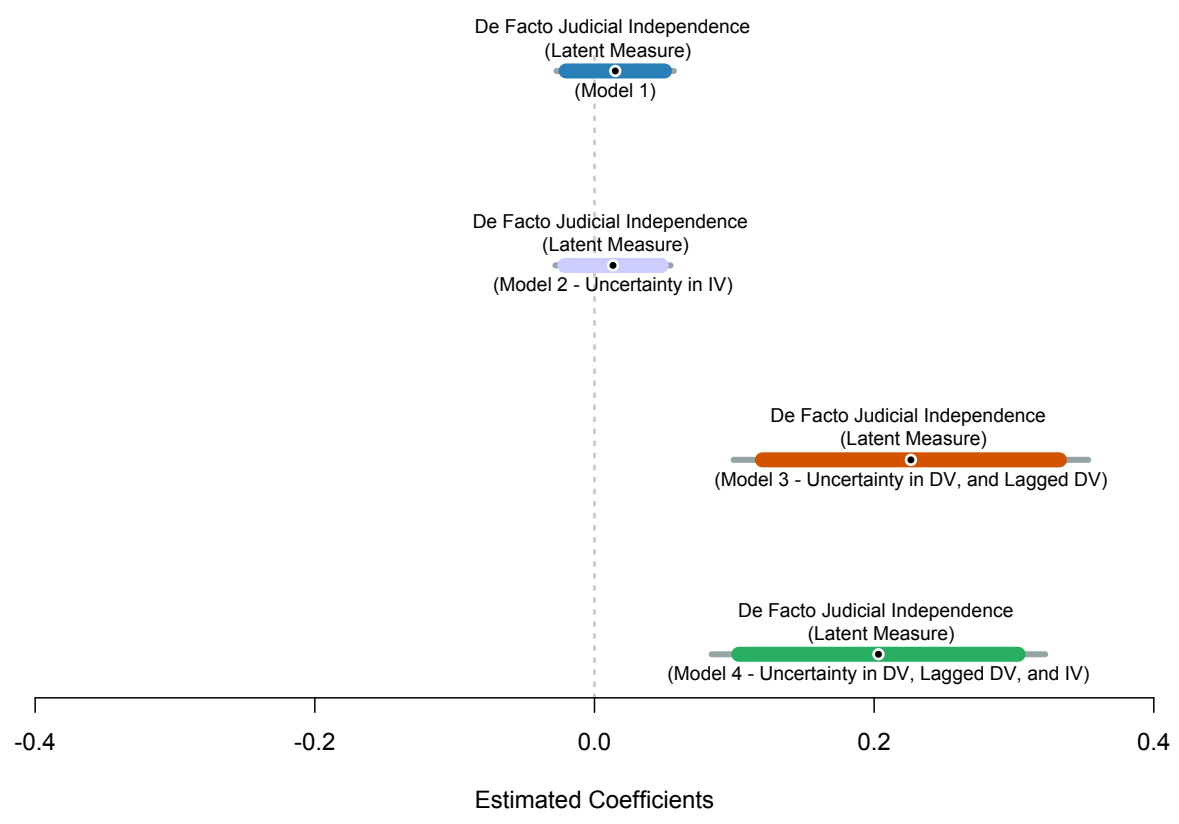

Note: Figure 6 plots the point estimates for de facto judicial independence from the four previous models. The bars on either side of the point estimates represent $90 \%$ and $95 \%$ confidence intervals. Confidence intervals are calculated with robust standard errors. The top model (blue line from Figure 1) regresses the point estimates for the latent human rights variable on the point estimates for the latent judicial independence measure in addition to the controls. The second model from the top regresses the point estimates for the latent human rights variable on 1000 draws from the latent judicial independence measure in addition to the controls. The third model from the top (orange line from Figure 2) regresses 1,000 draws from the latent human rights variable on the point estimates for the latent judicial independence measure in addition to the controls. The bottom model (green line from Figure 3) regresses 1, 000 draws from the latent human rights variable on 1,000 draws from the latent judicial independence measure in addition to the controls. See text for additional details. 
E. Extension of Keith, Tate And Poe (2009) 
To determine whether our findings are model or data dependent, we re-examine the relationship between de facto judicial independence and state respect for human rights using the model and data from Keith, Tate and Poe (2009). To ease the comparison of these results with those presented in the main text, we drop years prior to 1980 . We also exclude all cases in which we do not have country-year observations for the Unified Democracy Scores (UDS) measure, as we estimate a model with the UDS measure in Appendix F. The resulting data set comprises 2257 country-year observations from 1980-1996.

The figures and tables below present the findings form this analysis. They provide strong support for the claim that de facto judicial independence is positively correlated with state respect for human rights. That we obtain similar findings using across models and datasets increases our confidence in this finding.

Figure 3: Effect of De Facto Judicial Independence on State Respect for Human Rights

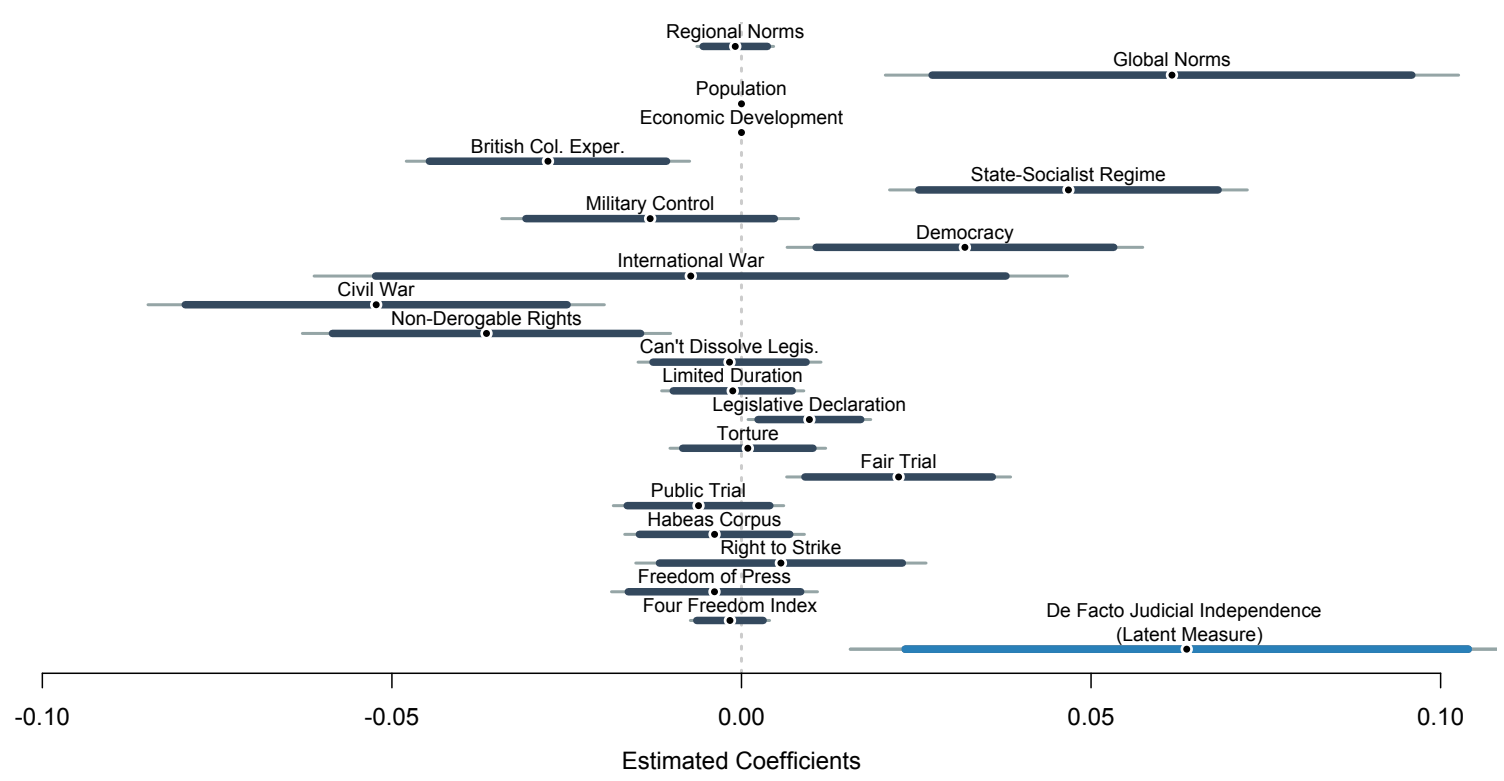

Note: Figure 1 presents the results of an OLS model, Model 1 in Table 1, that estimates the effect of many possible determinants on state respect for human rights. The bars on either side of the point estimates represent $90 \%$ and $95 \%$ confidence intervals. Confidence intervals are calculated with robust standard errors. While we include a lagged outcome measure in our model, we do not present an estimate for it here. See text for additional details. 
Figure 4: Effect of De Facto Judicial Independent on State Respect for Human Rights (Accounting for Uncertainty in the Outcome Measure and the Lagged Outcome Measure)

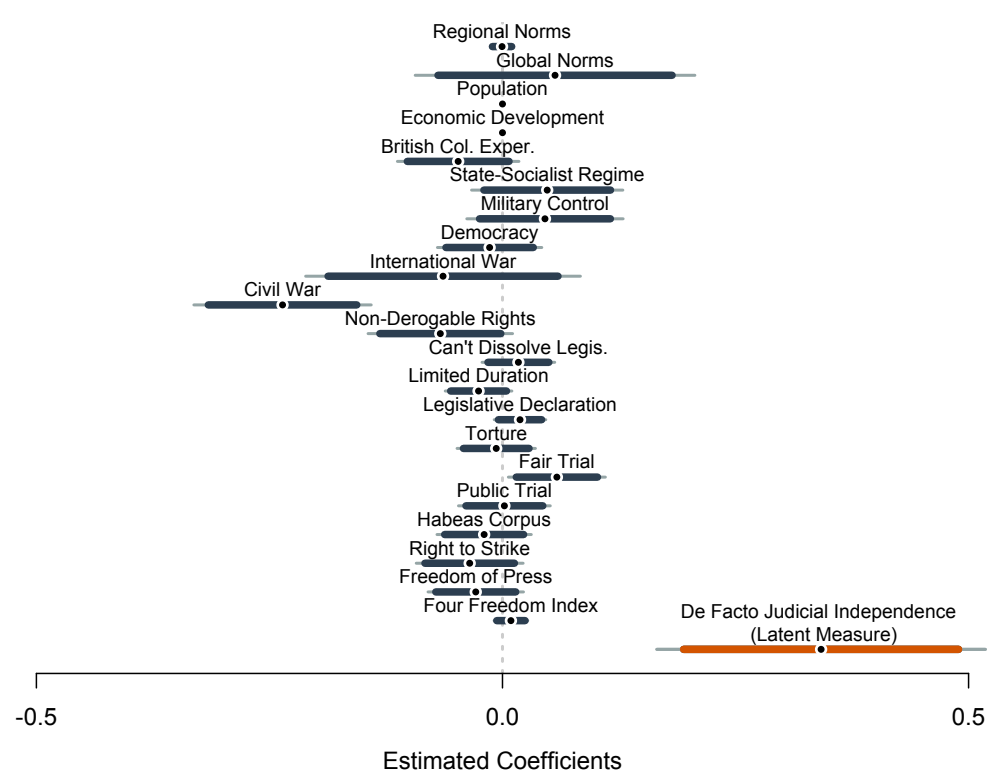

Note: Figure 2 presents the averaged results of 1,000 OLS models, each of which was estimated on a different set of draws from the posterior distribution of the outcome measure and the lagged outcome measure. The combined results of these models are presented in Model 2 in Table 1. The bars on either side of the point estimates represent $90 \%$ and $95 \%$ confidence intervals. Confidence intervals are calculated with robust standard errors. While we include a lagged outcome measure in our model, we do not present an estimate for it here. See text for additional details. 
Figure 5: Effect of De Facto Judicial Independent on State Respect for Human Rights (Accounting for Uncertainty in the Outcome Measure, the Lagged Outcome Measure, and the Independent Variable)

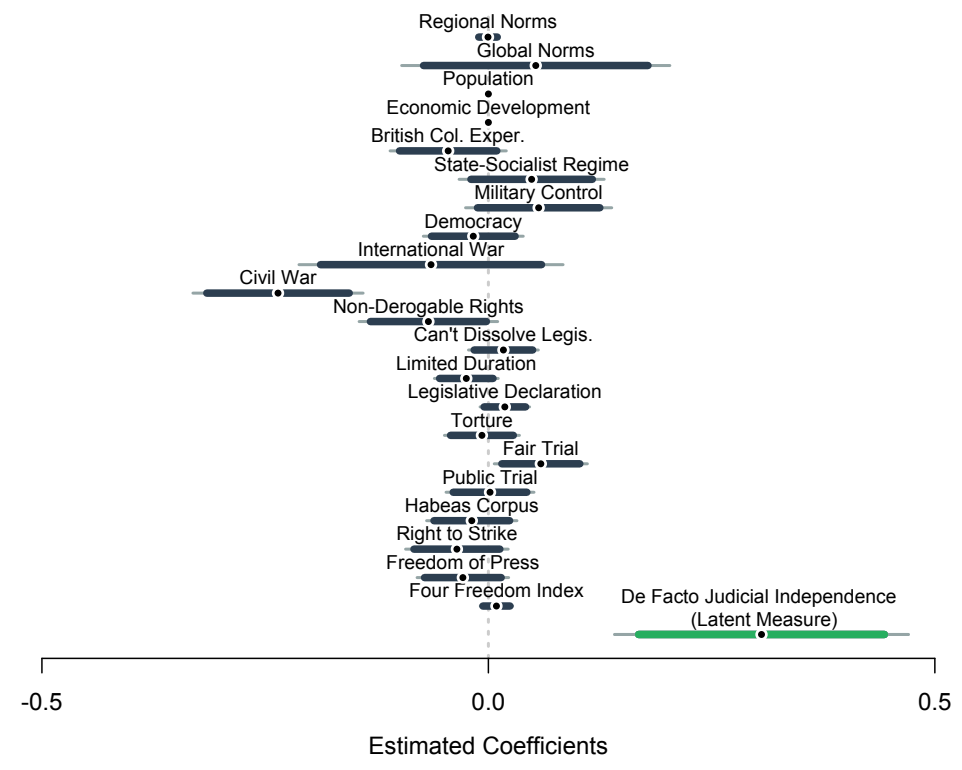

Note: Figure 3 presents the averaged results of 1,000 OLS models, each of which was estimated on a different set of draws from the posterior distribution of the outcome measure, the lagged outcome measure, and the primary independent variable. The combined results of these models are presented in Model 3 in Table 1. The bars on either side of the point estimates represent $90 \%$ and $95 \%$ confidence intervals. Confidence intervals are calculated with robust standard errors. While we include a lagged outcome measure in our model, we do not present an estimate for it here. See text for additional details. 


\section{Figure 6: Comparing the Effect of De Facto Judicial Independence Across Models}

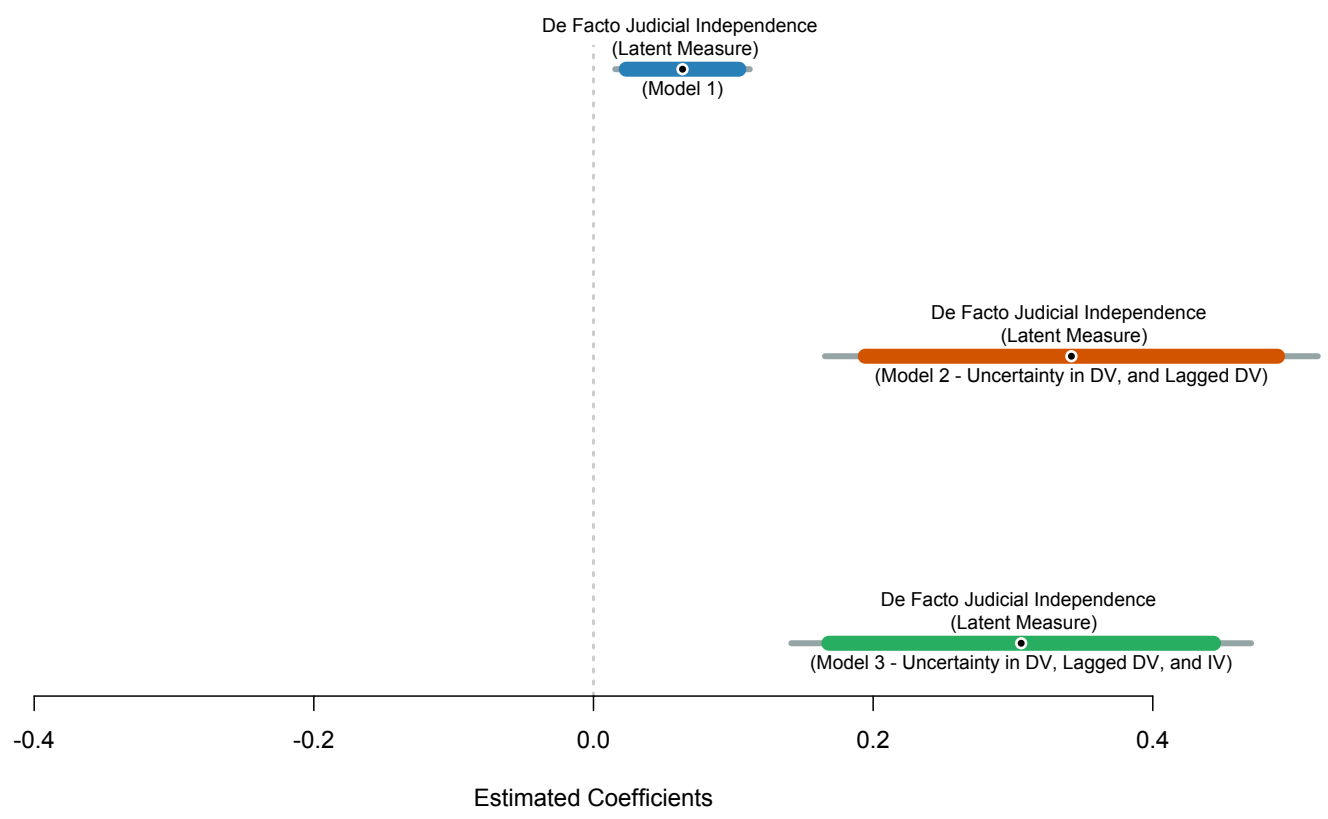

Note: Figure 4 plots the point estimates for de facto judicial independence from the three previous models. The bars on either side of the point estimates represent $90 \%$ and $95 \%$ confidence intervals. Confidence intervals are calculated with robust standard errors. The top model (blue line from Figure 1) regresses the point estimates for the latent human rights variable on the point estimates for the latent judicial independence measure in addition to the controls. The middle model (orange line from Figure 2) regresses 1,000 draws from the latent human rights variable on the point estimates for the latent judicial independence measure in addition to the controls. The lower model (green line from Figure 3) regresses 1,000 draws from the latent human rights variable on 1,000 draws from the latent judicial independence measure in addition to the controls. See text for additional details. 
Figure 7: Cross-Validation Results

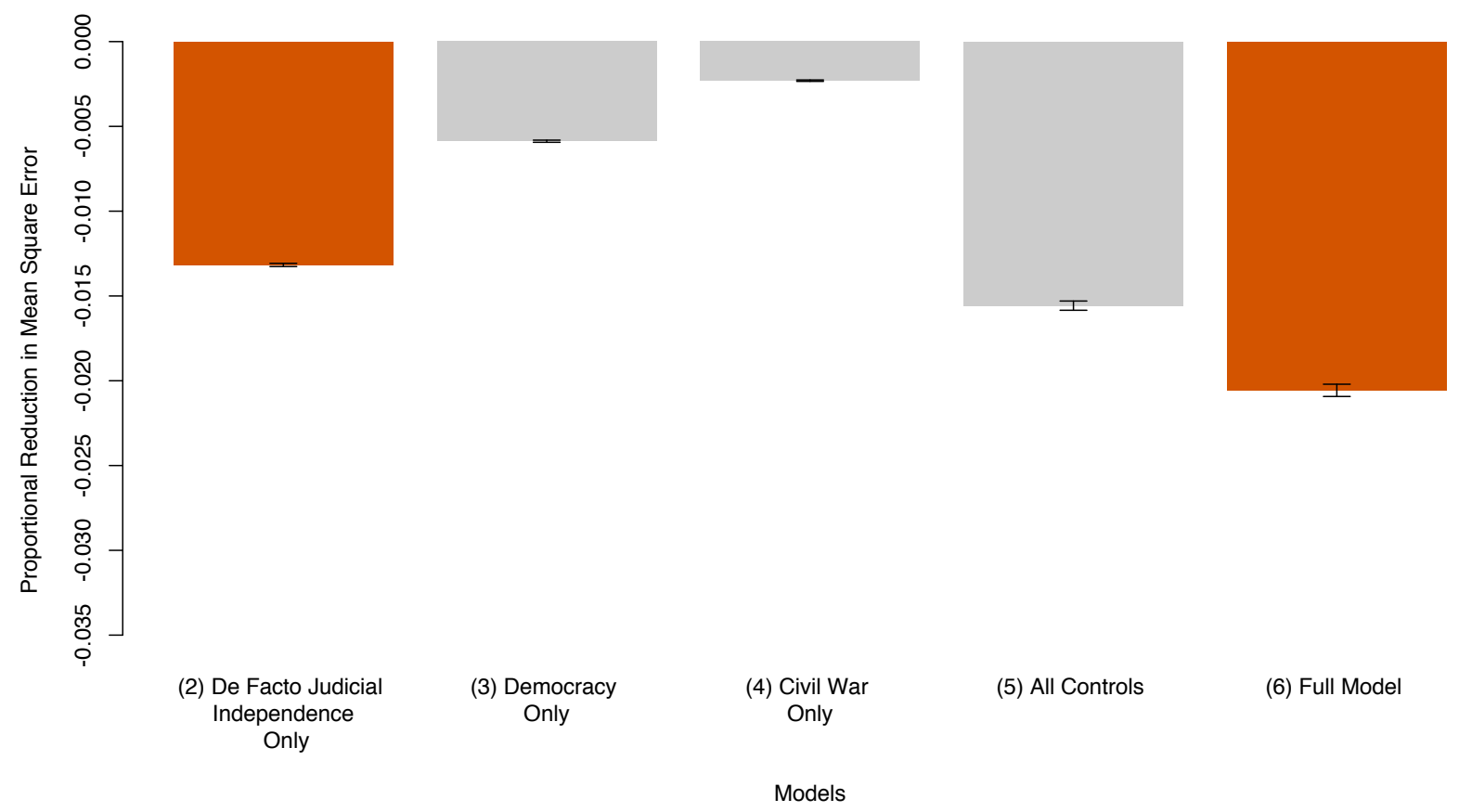

Note: Figure 5 plots the average percent reduction in mean square error of each model compared to the baseline model, which includes only the lagged outcome measure, revealing the additional predictive power of individual variables and combinations of variables. Each bar in the figure corresponds to a model reported in Table 2. Model 1 is the baseline model that all other models are compared to. Thus, Bar 2 corresponds to Model 2, Bar 3 corresponds to Model 3, Bar 4 corresponds to Model 4, Bar 5 corresponds to Model 5, and Bar 6 corresponds to Model 6. The black lines bracketing the end of each column represent $95 \%$ confidence intervals. See text for additional details. 
Table 4: State Respect for Human Rights Across Countries (1979-1996)

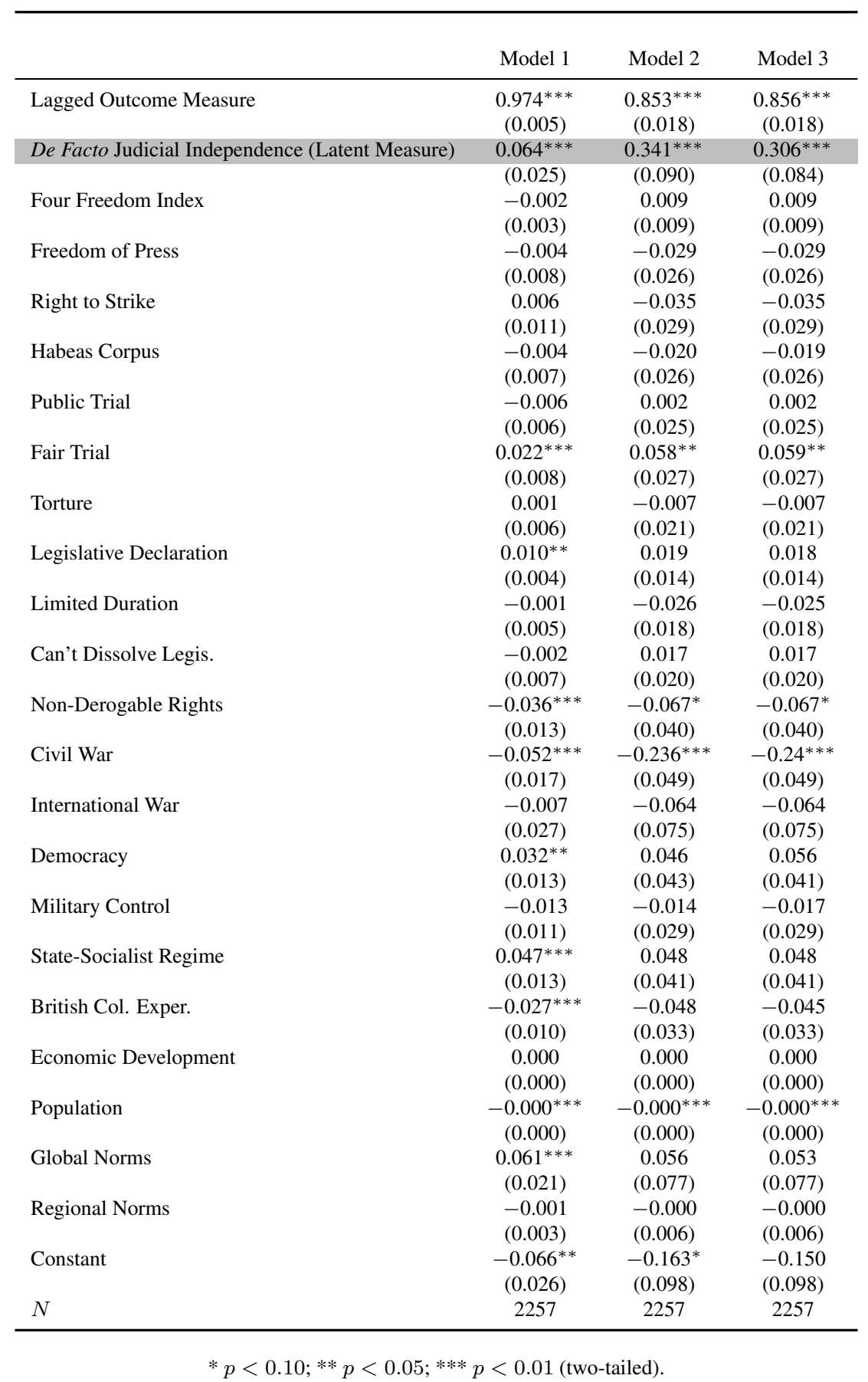

Note: Robust standard errors are shown in parentheses. All models account for uncertainty in the outcome measure, the lagged outcome measure, and the indepndent variable. Data come from 2257 country-year observations from 1980 to 1996. The outcome measure is State Respect for Human Rights. See Keith, Tate and Poe (2009) for more information about the model and data. 
Table 5: State Respect for Human Rights Across Countries (1979-1996) - Models Used for Cross Validation

\begin{tabular}{|c|c|c|c|c|c|c|}
\hline & Model 1 & Model 2 & Model 3 & Model 4 & Model 5 & Model 6 \\
\hline Lagged Outcome Measure & $\begin{array}{c}0.950^{* * *} \\
(0.013)\end{array}$ & $\begin{array}{c}0.903^{* * *} \\
(0.014)\end{array}$ & $\begin{array}{c}0.933^{* * *} \\
(0.013)\end{array}$ & $\begin{array}{c}0.941^{* * *} \\
(0.014)\end{array}$ & $\begin{array}{c}0.876^{* * *} \\
(0.017)\end{array}$ & $\begin{array}{c}0.856^{* * *} \\
(0.018)\end{array}$ \\
\hline De Facto Judicial Independence (Latent Measure) & - & $0.308^{* * *}$ & - & - & - & $0.300^{* * *}$ \\
\hline & - & $(0.052)$ & - & - & - & $(0.085)$ \\
\hline Democracy & - & - & $\begin{array}{c}0.110^{* * *} \\
(0.026)\end{array}$ & - & $\begin{array}{c}0.149^{* * *} \\
(0.033)\end{array}$ & $\begin{array}{c}0.060 \\
(0.042)\end{array}$ \\
\hline Civil War & - & $\begin{array}{l}- \\
-\end{array}$ & - & $\begin{array}{c}-0.133^{* * *} \\
(0.044)\end{array}$ & $\begin{array}{c}-0.235^{* * *} \\
(0.049)\end{array}$ & $\begin{array}{c}-0.238^{* * *} \\
(0.048)\end{array}$ \\
\hline Four Freedom Index & - & - & - & - & $\begin{array}{c}0.009 \\
(0.010)\end{array}$ & $\begin{array}{c}0.009 \\
(0.009)\end{array}$ \\
\hline Freedom of Press & - & - & - & $\begin{array}{l}- \\
-\end{array}$ & $\begin{array}{l}-0.027 \\
(0.027)\end{array}$ & $\begin{array}{l}-0.028 \\
(0.027)\end{array}$ \\
\hline Right to Strike & $\begin{array}{l}- \\
-\end{array}$ & $\begin{array}{l}- \\
-\end{array}$ & $\begin{array}{l}- \\
-\end{array}$ & - & $\begin{array}{l}-0.036 \\
(0.029)\end{array}$ & $\begin{array}{l}-0.036 \\
(0.028)\end{array}$ \\
\hline Habeas Corpus & - & - & - & - & $\begin{array}{l}-0.010 \\
(0.026)\end{array}$ & $\begin{array}{l}-0.019 \\
(0.026)\end{array}$ \\
\hline Public Trial & - & - & $\begin{array}{l}- \\
-\end{array}$ & - & $\begin{array}{l}-0.000 \\
(0.026)\end{array}$ & $\begin{array}{c}0.002 \\
(0.025)\end{array}$ \\
\hline Fair Trial & - & - & - & - & $\begin{array}{c}0.062^{* *} \\
(0.027)\end{array}$ & $\begin{array}{c}0.059^{* *} \\
(0.026)\end{array}$ \\
\hline Torture & - & - & - & - & $\begin{array}{l}-0.012 \\
(0.021)\end{array}$ & $\begin{array}{l}-0.007 \\
(0.021)\end{array}$ \\
\hline Legislative Declaration & - & - & - & - & $\begin{array}{c}0.015 \\
(0.014)\end{array}$ & $\begin{array}{c}0.018 \\
(0.014)\end{array}$ \\
\hline Limited Duration & - & - & - & - & $\begin{array}{l}-0.017 \\
(0.018)\end{array}$ & $\begin{array}{l}-0.025 \\
(0.018)\end{array}$ \\
\hline Can't Dissolve Legis. & - & - & - & - & $\begin{array}{c}0.015 \\
(0.020)\end{array}$ & $\begin{array}{c}0.017 \\
(0.020)\end{array}$ \\
\hline Non-Derogable Rights & - & - & $\begin{array}{l}- \\
-\end{array}$ & - & $\begin{array}{c}-0.072^{*} \\
(0.040)\end{array}$ & $\begin{array}{c}-0.068^{*} \\
(0.040)\end{array}$ \\
\hline International War & - & - & - & - & $\begin{array}{l}-0.070 \\
(0.075)\end{array}$ & $\begin{array}{c}-0.066 \\
(0.074)\end{array}$ \\
\hline Military Control & - & - & $\begin{array}{l}- \\
-\end{array}$ & - & $\begin{array}{l}-0.043 \\
(0.028)\end{array}$ & $\begin{array}{l}-0.017 \\
(0.028)\end{array}$ \\
\hline State-Socialist Regime & - & - & - & - & $\begin{array}{c}0.054 \\
(0.041)\end{array}$ & $\begin{array}{c}0.051 \\
(0.041)\end{array}$ \\
\hline British Col. Exper. & - & - & - & - & $\begin{array}{l}-0.024 \\
(0.033)\end{array}$ & $\begin{array}{l}-0.044 \\
(0.034)\end{array}$ \\
\hline Economic Development & - & - & $\begin{array}{l}- \\
-\end{array}$ & - & $\begin{array}{c}0.000^{* *} \\
(0.000)\end{array}$ & $\begin{array}{c}0.000 \\
(0.000)\end{array}$ \\
\hline Population & - & - & - & - & $\begin{array}{c}-0.000^{* * *} \\
(0.000)\end{array}$ & $\begin{array}{c}-0.000^{* * *} \\
(0.000)\end{array}$ \\
\hline Global Norms & - & - & - & - & $\begin{array}{c}0.027 \\
(0.078)\end{array}$ & $\begin{array}{c}0.055 \\
(0.077)\end{array}$ \\
\hline Regional Norms & - & - & - & - & $\begin{array}{l}-0.000 \\
(0.006)\end{array}$ & $\begin{array}{c}-0.000 \\
(0.006)\end{array}$ \\
\hline Constant & $\begin{array}{c}0.032^{* *} \\
(0.012)\end{array}$ & $\begin{array}{c}-0.108^{* * *} \\
(0.025)\end{array}$ & $\begin{array}{l}-0.015 \\
(0.016)\end{array}$ & $\begin{array}{c}0.043^{* * *} \\
(0.012)\end{array}$ & $\begin{array}{l}-0.045 \\
(0.097)\end{array}$ & $\begin{array}{l}-0.151 \\
(0.098)\end{array}$ \\
\hline$N$ & 2255 & 2255 & 2255 & 2255 & 2255 & 2255 \\
\hline
\end{tabular}

$* p<0.10 ; * * p<0.05 ; * * * p<0.01$ (two-tailed).

Note: Robust standard errors are shown in parentheses. Data come from 2255 country-year observations from 1980 to 1996. The outcome measure is State Respect for Human Rights. See Keith, Tate and Poe (2009) for more information about the model and data. 
F. Models With Unified Democracy Score MeAsure 
We replace the DD measure of democracy with a latent variable measure, the Unified Democracy Scores (UDS), and re-examine the relationship between de facto judicial independence and state respect for human rights. The extent to which scholars should prefer the UDS measure to the DD measure depends on how they conceptualize democracy. If they think that democracy is unobservable and that there are degrees of democracy, they should prefer the UDS measure. If they think that democracy is observable and that states are either democratic or not, they should prefer the DD measure. While we think that the continuing debate about whether and how democracy can be measured is important, we leave that debate to others.

Table 8 presents the results our analysis. After replacing the DD measure with the UDS measure in Model 3 from Table 1, the results change. Column 1 in Table Table 8 shows that de facto judicial independence is no longer a strong predictor of increased state respect for human rights. In marked contrast, the results from the Keith, Tate and Poe (2009) model, presented in column 2 in Table 8, are consistent with the models reported in the manuscript.

One explanation for the null finding regarding de facto judicial independence is that the UDS measure and the Linzer and Staton (2011) measure are highly correlated. The point estimates from these two measures correlate at 0.894 in the dataset used to estimate Model 3 in Table 1, while they correlate at 0.846 in the data used to estimate Model 1 in Appendix E. The small difference in the degree to which these measures correlate across datasets is unlikely to explain the conflicting findings. This suggests that one of the models could be misspecified. More likely however, is the possibility that the latent UDS measure and the human rights measure are measure overlapping theoretical concepts as suggested by Hill Jr (2014); Hill Jr and Jones (2014). As we discussed in the manuscript, most earlier human rights studies use Polity or Freedom House measures of democracy. Again however, this choice is problematic because the Polity and Freedom House indicators classify regimes, in part, based on their respect for human rights (Hill Jr, 2014; Hill Jr and Jones, 2014). This conceptual and empirical overlap make it difficult to disentangle the independent associations between human rights and democracy in these models. The conceptual overlap is severe between the de facto judicial independence and the UDS measures. It is not 
surprising that these three variables all co-vary. Disentangling the conceptual overlap between some of the democracy indicators included in the estimate of the UDS variable and measures of human rights is an ongoing research project (e.g., Hill Jr and Jones, 2014). We believe that future research should also look at the conceptual and empirical overlap between the Linzer and Staton (2011) measure and the UDS measure as well. 
Table 6: State Respect for Human Rights Across Countries - UDS Measure

\begin{tabular}{|c|c|c|}
\hline & Model 1 & Model 2 \\
\hline Lagged Outcome Measure & $\begin{array}{c}0.853^{* * *} \\
(0.015)\end{array}$ & $\begin{array}{c}0.847^{* * *} \\
(0.018)\end{array}$ \\
\hline De Facto Judicial Independence (Latent Measure) & 0.070 & $0.233^{* *}$ \\
\hline & $(0.074)$ & $(0.102)$ \\
\hline Four Freedom Index & $\begin{array}{l}- \\
-\end{array}$ & $\begin{array}{c}0.008 \\
(0.010)\end{array}$ \\
\hline Freedom of Press & $\begin{array}{l}- \\
-\end{array}$ & $\begin{array}{l}-0.036 \\
(0.028)\end{array}$ \\
\hline Right to Strike & $\begin{array}{l}- \\
-\end{array}$ & $\begin{array}{l}-0.044 \\
(0.030)\end{array}$ \\
\hline Habeas Corpus & - & $\begin{array}{l}-0.021 \\
(0.027)\end{array}$ \\
\hline Public Trial & - & $\begin{array}{c}0.004 \\
(0.026)\end{array}$ \\
\hline Fair Trial & - & $\begin{array}{c}0.062^{* *} \\
(0.027)\end{array}$ \\
\hline Torture & $\begin{array}{l}- \\
-\end{array}$ & $\begin{array}{c}--0.006 \\
(0.022)\end{array}$ \\
\hline Legislative Declaration & $\begin{array}{l}- \\
-\end{array}$ & $\begin{array}{c}0.022 \\
(0.015)\end{array}$ \\
\hline Limited Duration & $\begin{array}{l}- \\
-\end{array}$ & $\begin{array}{l}-0.024 \\
(0.018)\end{array}$ \\
\hline Can't Dissolve Legis. & - & $\begin{array}{c}0.015 \\
(0.020)\end{array}$ \\
\hline Non-Derogable Rights & - & $\begin{array}{l}-0.064 \\
(0.040)\end{array}$ \\
\hline Civil War & $\begin{array}{c}-0.161^{* * *} \\
(0.036)\end{array}$ & $\begin{array}{c}-0.235^{* * *} \\
(0.049)\end{array}$ \\
\hline International War & $\begin{array}{l}-0.027 \\
(0.081)\end{array}$ & $\begin{array}{l}-0.058 \\
(0.078)\end{array}$ \\
\hline Democracy (UDS) & $\begin{array}{c}0.064^{* *} \\
(0.022)\end{array}$ & $\begin{array}{l}0.054^{*} \\
(0.030)\end{array}$ \\
\hline Military Control & $\begin{array}{l}-0.026 \\
(0.023)\end{array}$ & $\begin{array}{l}-0.027 \\
(0.029)\end{array}$ \\
\hline State-Socialist Regime & $\begin{array}{c}0.057 \\
(0.036)\end{array}$ & $\begin{array}{c}0.054 \\
(0.042)\end{array}$ \\
\hline British Col. Exper. & $\begin{array}{l}-0.022 \\
(0.023)\end{array}$ & $\begin{array}{l}-0.051 \\
(0.034)\end{array}$ \\
\hline Economic Development & $\begin{array}{c}0.000^{* * *} \\
(0.000)\end{array}$ & $\begin{array}{c}0.000^{* * *} \\
(0.000)\end{array}$ \\
\hline Economic Growth & $\begin{array}{c}0.002 \\
(0.002)\end{array}$ & $\begin{array}{l}- \\
-\end{array}$ \\
\hline Population & - & $\begin{array}{c}-0.000^{* * *} \\
(0.000)\end{array}$ \\
\hline Logged Population & $\begin{array}{c}-0.045^{* * *} \\
(0.007)\end{array}$ & - \\
\hline Population Growth & $\begin{array}{l}-0.004 \\
(0.007)\end{array}$ & - \\
\hline Global Norms & - & $\begin{array}{c}0.053 \\
(0.079)\end{array}$ \\
\hline Regional Norms & - & $\begin{array}{l}-0.001 \\
(0.006)\end{array}$ \\
\hline Constant & $\begin{array}{c}0.707^{* * *} \\
(0.117)\end{array}$ & $\begin{array}{c}-0.0748 \\
(0.110)\end{array}$ \\
\hline$N$ & 3015 & 2255 \\
\hline
\end{tabular}

$* p<0.10 ; * * p<0.05 ; * * * p<0.01$ (two-tailed).

Note: Robust standard errors are shown in parentheses. Data for Model 1 come from 3013 country-year observations from 1980 to 2004 . Data for Model 2 come from 2255 country-year observations from 1980 to 1996. The outcome measure is State Respect for Human Rights. See Keith, Tate and Poe (2009) and Keith (2012) for more information about the model and data. 
G. Notes On ESTIMATOR CHOICE 
We use an OLS estimator in our analysis because the latent human rights variable is an intervallevel, continuous variable. Using a continuous measure, instead of the standard ordered categorical human rights variables common in the literature, opens up all of the well known econometric techniques available for estimating continuous outcome measures in panel data settings (e.g., Arellano and Bond, 1991; Beck and Jackman, 1998; Beck and Katz, 1995, 2011; Blundell and Bond, 1998; M.Wooldridge, 2010). Moving beyond the use of these frequentist tools, Bayesian hierarchical models for panel data may also be useful for exploring the dynamic relationships between different latent variables (Gelman and Hill, 2007; Western, 1998). A particular advantage of these models is that they can find breaks or change points in the different series (e.g., Barry and Hartigan, 1993; Chib, 1998; Ratkovic and Eng, 2010).The exploration all of these estimation choices is an important new research opportunity for human rights scholars but a detailed discussion of the relative benefits of each choice is beyond the scope of this research note. Though we do not yet have concrete suggestions for which estimator is the most optimal for estimating the relationship between continuous, the tools briefly highlighted here are useful starting points for applied researchers. We also add that the model building and validation processes should always go hand in hand, which Gelman and Shalizi (20) defines as a process of continuous model expansion. 


\section{REFERENCES}

Arellano, Manuel and Stephen Bond. 1991. "Some Tests of Specification for Panel Data: Monte Carlo Evidence and an Application to Employment Equations." The Review of Economic Studies 58(2):277-297.

Barry, Daniel and J. A. Hartigan. 1993. “A Bayesian Analysis for Change Point Problems.” Journal of the American Statistical Association 88(421):309-319.

Beck, Nathaniel and Jonathan N. Katz. 1995. "What to do (and not to do) with Time-Series CrossSection Data." American Political Science Review 89(3):634-647.

Beck, Nathaniel and Jonathan N. Katz. 2011. "Modeling dynamics in Time-Series-CrossSection political economy data." Annual Review of Political Science 14(331-352).

Beck, Nathaniel and Simon Jackman. 1998. "Beyond Linearity by Default: Generalized Additive Models.” American Journal of Political Science 42(2):596-627.

Blundell, Richard and Stephen Bond. 1998. "Initial conditions and moment restrictions in dynamic panel data models." Journal of Econometrics 87:115-143.

Cheibub, José Antonio, Jennifer Gandhi and James Raymond Vreeland. 2010. "Democracy and dictatorship revisited." Public Choice 143(1-2):67-101.

Chib, Siddharta. 1998. "Estimation and comparison of multiple change-point models." Journal of Econometrics 86:221-224.

Fariss, Christopher J. 2014. "Respect for Human Rights Has Improved Over Time: Modeling the Changing Standard of Accountability.” American Political Science Review 108(2):297-318.

Geddes, Barbara, Joseph Wright and Erica Frantz. 2014. "Autocratic Breakdown and Regime Transitions: A New Data Set." Perspectives on Politics 14.

Gelman, Andrew and Cosma Rohilla Shalizi. 20. "Philosophy and the practice of Bayesian statistics.” British Journal of Mathematical and Statistical Psychology 66(1):8-38.

Gelman, Andrew and Jennifer Hill. 2007. Data analysis using regression and multilevel/hierarchical models. Cambridge, MA: Cambridge University Press.

Hallberg, Johan Dittrich. 2012. "PRIO Conflict Site 1989-2008: A geo-referenced dataset on armed conflict." Conflict Management and Peace Science 29(2):219-232.

Hill Jr, Daniel W. 2014. "Democracy and The Concept of Personal Integrity Rights In Empirical Research.”.

Hill Jr, Daniel W and Zachary M Jones. 2014. An Empirical Evaluation of Explanations for State Repression. In American Political Science Review. Vol. 108 pp. 661-687.

Keith, Linda Camp. 2012. Political Repression Courts and the Law. University of Pennsylvania Press. 
Keith, Linda Camp, C Neal Tate and Steven C Poe. 2009. "Is the Law a Mere Parchment Barrier to Human Rights Abuse?” The Journal of Politics 71(02):644-660.

Linzer, Drew A and Jeffrey K Staton. 2011. A measurement model for synthesizing multiple comparative indicators: The case of judicial independence. In presentation at the 2011 Annual Meeting of the American Political Science Association, September. pp. 1-4.

Melton, James, Stephen Meserve and Daniel Pemstein. 2011. "Unifed Democracy Scores.".

URL: http://www.unified-democracy-scores.org

M.Wooldridge, Jeffrey. 2010. Econometric Analysis of Cross-Sectional and Panel Data. 2nd edition ed. MIT Press.

Ratkovic, Marc T. and Kevin H. Eng. 2010. "Finding Jumps in Otherwise Smooth Curves: Identifying Critical Events in Political Processes.” Political Analysis 18(1):57-77.

Western, Bruce. 1998. "Causal Heterogeneity in Comparative Research: A Bayesian Hierarchical Modeling Approach.” American Journal of Political Science 42(4):1233-1259. 